\title{
An Analysis of the Effects of Monetary and Fiscal Policies on the Current Account Deficit in Selected Oil Exporting Countries: A P-VAR Approach
}

\author{
Arezoo Nasirpour ${ }^{1}$ \\ Hossein Sharifi-Renani ${ }^{2}$ \\ Saeed Daei Karimzadeh ${ }^{3}$ \\ Mehdi Basirat ${ }^{4}$
}

h.sharifi@khuisf.ac.ir

karimzadeh@khuisf.ac.ir

\begin{abstract}
One of the important economic variables related to the foreign balance of countries is the current account balance of payments. Current account balance and budget balance are considered as important indicators of macroeconomic stability and welfare. The growing disequilibrium of the current account balance and the government budget balance lead to a macroeconomic imbalance. This paper analyzes the effects of monetary and fiscal policies on current account deficits in selected oil-exporting countries (Algeria, Colombia, Ecuador, Gabon, Iran, Mexico, Nigeria, Saudi Arabia, Kuwait, Angola, Congo, Indonesia, Malaysia, Trinidad, and Tobago) for the period 2000-2015 using a Panel Vector Autoregressive (P-VAR) model. The results indicate that monetary policy (by raising interest rates) will decrease the current account deficit. Considering that, in this research budget deficit coefficient is positive, as budget deficit increases (fiscal policy), the current account deficit decreases. In other words, the twin divergence hypothesis is approved for this group of countries, during the period under review. With increasing oil revenues, current account deficits will increase.
\end{abstract}

Keywords: Monetary Policy, Fiscal Policy, Current Account, P-VAR Model, Oil Exporting Countries.

JEL Classification: E62, F32, C33, Q3.

1. Ph.D. Student, Department of Economics, Islamic Azad University, Isfahan (Khorasgan) Branch, Isfahan, Iran.

2. Associate Professor, Department of Economics, Islamic Azad University, Isfahan (Khorasgan) Branch, Isfahan, Iran (Corresponding Author).

3. Associate Professor, Department of Economics, Islamic Azad University, Isfahan (Khorasgan) Branch, Isfahan, Iran.

4. Assistant professor, Department of Economics, Islamic Azad University, Ahvaz Branch, Ahvaz, Iran. 


\section{تحليل اثرهاى سياستهاى يولى و مالى بر كسرى

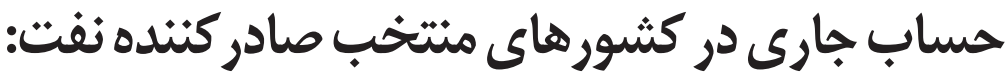 رهيافت خودر}

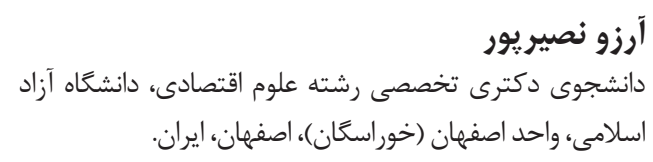

h.sharifi@khuisf.ac.ir حسين شريفى رنانى دانشيار تروه اقتصاد، دانشَاه آزاد اسلامى، واحد اصفهان (خوراسكان)، اصفهان، ايران (نويسنده مسئول). karimzadeh@khuisf.ac.ir । سعيد دايى كريمزاده دانشيار تروه اقتصاد، دانشَاه آزاد اسلامى، واحد اصفهان (خوراسكان)، اصفهان، ايران.

مهدى بصيرت استاديار گروه اقتصاد، دانشكاه آزاد اسلامى، واحد اهواز، اهواز، ايران.

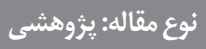

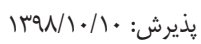

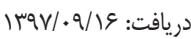
קُكيده: حساب جارى تراز يرداختها يكى از متغيرهاى مههم اقتصادى مرتبط با تراز خارجى

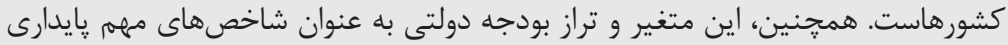

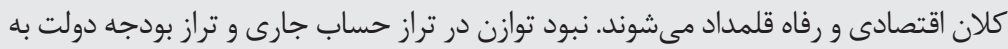

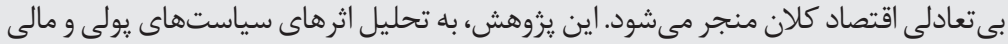

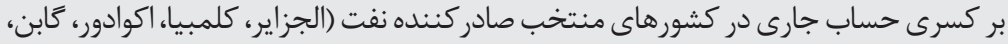

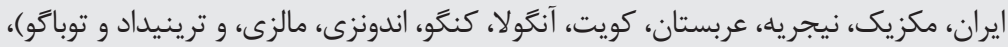

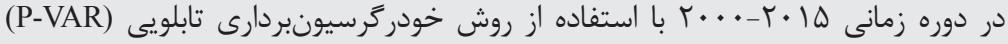

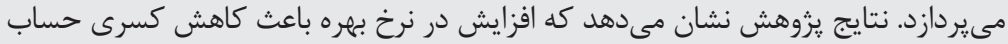

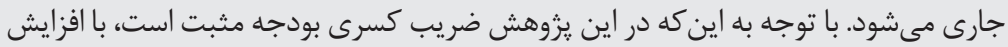

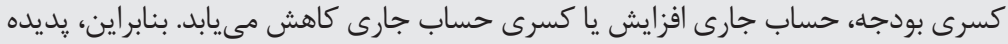

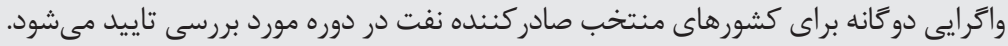
همجنين، با افزايش در آمدهاى نفتى نيزئ، كسرى مساب مساب جارى افزايش مى ميابد.

كليدوازهها: سياست يولى، سياست مالى، حساب جارى، مدل P-VAR، كشورهاى صادر كنندهنفت طبقهبندى Q.J3, C33, F32, E62 : 


\section{هoloto}

تراز يرداختهاى خارجى معيار مههى براى سنجش جريان مبادلههاى تجارى و انتقال سرمايه

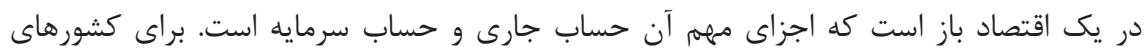
درحالتوسعه تراز يرداختها و وضعيت تراز حساب جارى، از مهمترين متغيرها و محدوديتهاى برى

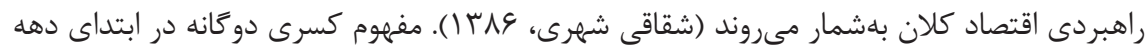

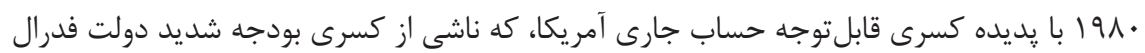
است، مطرح مىشود (Bartolini \& Lahiri, 2006). نياز به اشاره است كه اين مسئله در كشورهاى درحالتوسعه كه بخش خصوصى كارايى ندارند بهطور گَتردهترى مشاهده مىشود. در اين كشورها،

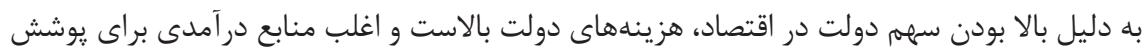

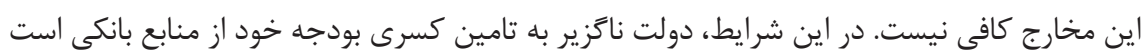

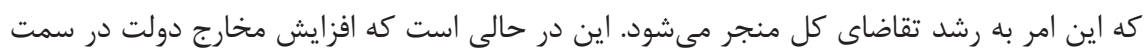

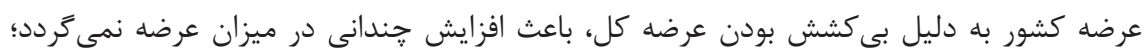

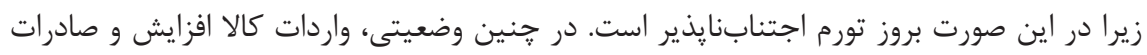

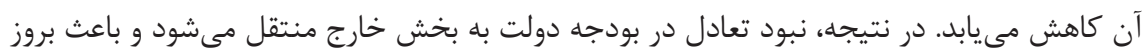

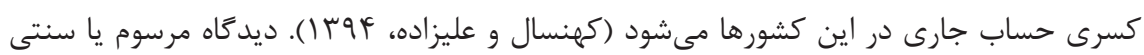
در خصوص كسرى دو گانه بر نقش مهرم كسرىهاى مالى در افزايش تمامى مولفههاى تقاضا از جمله

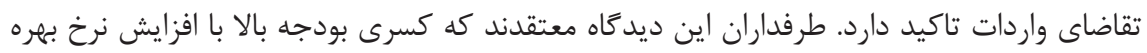
و تقويت يول داخلى به كسرى بيشتر حساب جارى منجر مىشود. در مقابل، نكرش ريكاردويى، از

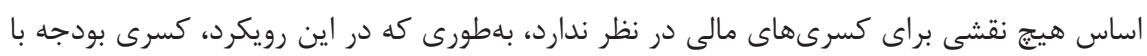

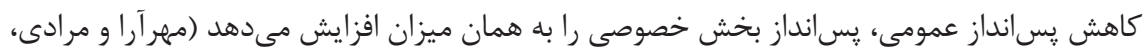

در يزوهش هاى ييشين، صرفاً ارتباط كسرى بودجه و كسرى حساب جارى براى ايران بررسى شده

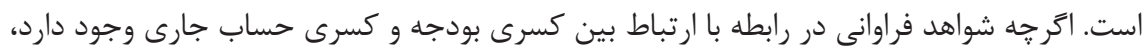

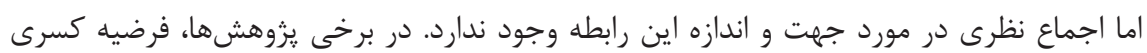

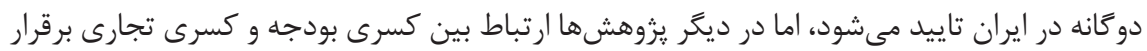

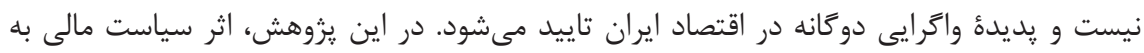
صورت كسرى بودجه و سياست يولى بر كسرى حساب جارى در كشورهاى صادركننده نفت در يك يك 
الكَى خودرگرسيونبردارى تابلويى در نظرَّفته مىشود. همجنين، با توجه به اينكه شوكهاى

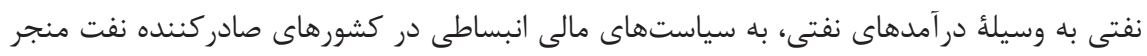

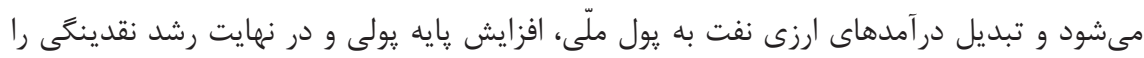

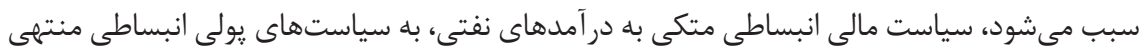

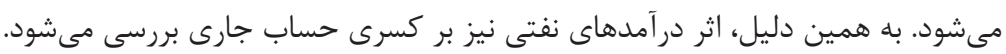

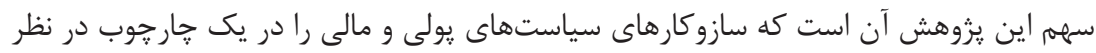

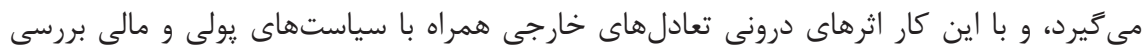

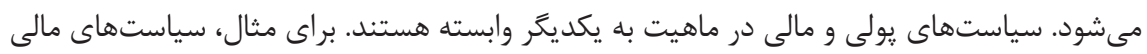

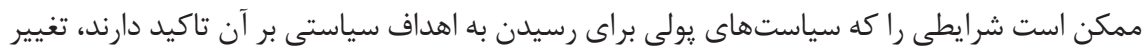
دهد در حالى كه سياستهاى يولى مىتوانند نسبت به سياستهاى مالى، تطبيقى يا خنثى كننده

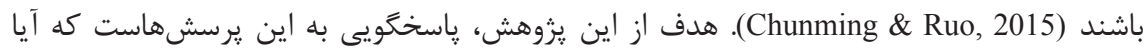

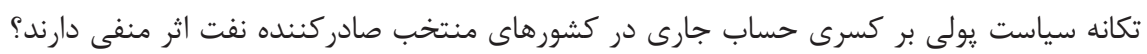
و آيا فرضيه كسرى دو كانه (ارتباط مثبت بين كسرى بودجه و كسرى حساب جارى)، در كشورهاى منتخب صادر كننده نفت تاييد مىشود؟

\section{مبانى نظرى يزوهش} كسرى حساب جارى

كسرى دوگانه' بيانكر رابطه مثبت بين كسرى بودجه و كسرى حساب جارى است. واگرايى

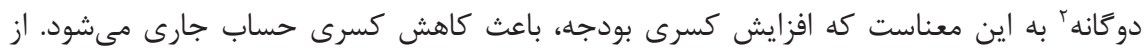

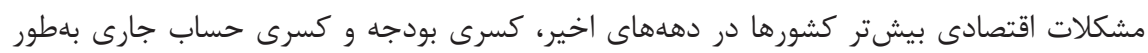
همزمان است. اين مشكل در كشورهاى درحالتوسعه بلطور گستردهترى مشاهده مىشود؛ زيرا اين

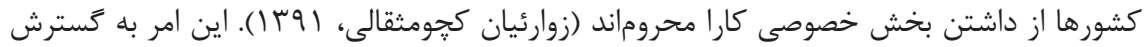

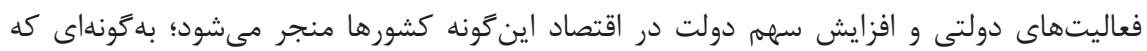
مخارج مصرفى و سرمايهگذارى دولت سهم عمدهاى از تقاضاى كل را به خود اختصاص مى دهند. در 
مقابل، در سمت درآمدى، دولت منابع درآمدى كافى براى يوشش مخارج كسترده خود ندارد. نتيجأ קنين فرايندى در اين كشورها جيزى جز ايجاد كسرى بودجه مداوم و مستمر نيست. اتر دولت در جنين وضعيتى براى تامين كسرى بودجه به منابع بانكى اتكا كند، سبب بروز تورم در اقتصاد مىشود،

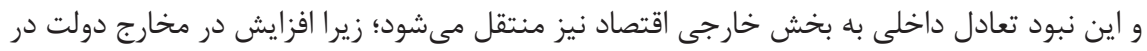

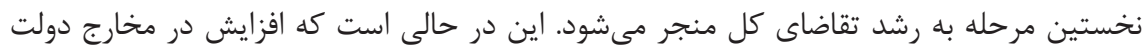

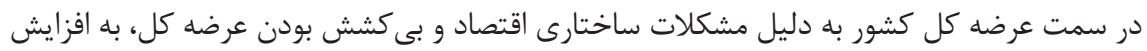

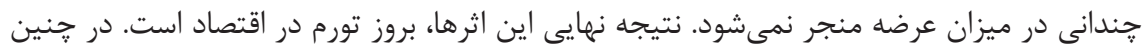

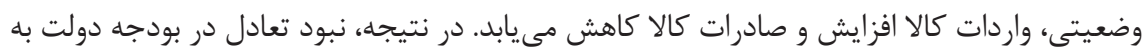
بخش خارج منتقل مىشود و سبب بروز كسرى حساب جارى در اين گونه كشورها مى شود (زوارئيان كجومثقالى، (1) (1) (1).

\section{كسرى دو كانه}

كسرى دوكانه نشاندهنده تاثير افزايش برونزاى كسرى بودجه بهطور غيرمستقيم بر پسانداز

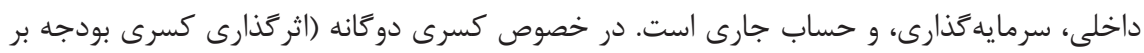
كسرى حساب جارى)، جهار ديدكاه متفاوت وجود دارد: فرضيه كسرى دوگانه: اين فرضيه بيان مى كند كه كسرى بودجه علت كسرى حساب جارى است.

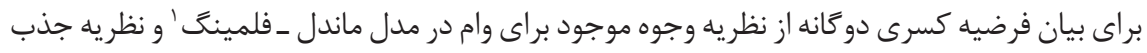

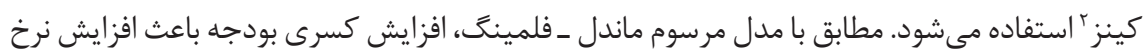

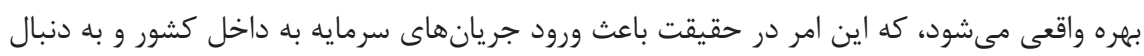

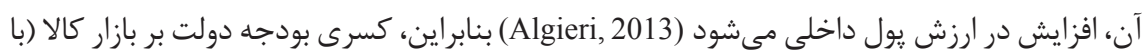
نرخ ارز)، و حساب سرمايه (با نرخ بهره واقعى) تاثير حذار است (Papadogonas \& Stournaras, 2006).

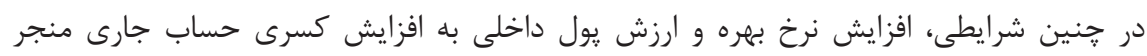

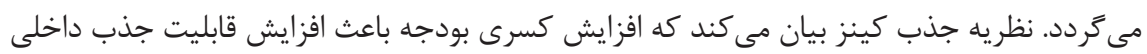
و در نتيجه، گسترش واردات مىشود كه اين امر به كسرى حساب جارى منتج مىشود. بنابراين،

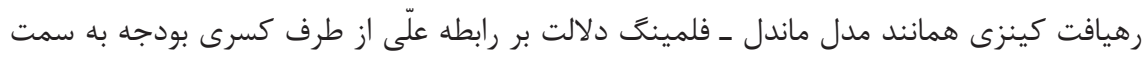
كسرى حساب جارى دارد و عكس اين رابطه برقرار نيست (Algieri, 2013).

1. Mundell-Fleming Model

2. Keynesian Theory of Attraction 
هدفگذارى بر پايه حساب جارى: اين امكان وجود دارد كه كسرى حساب جارى علت كسرى بودجه باشد. اين ارتباط معكوس تحت عنوان هدفكذارى بر يايه حساب جارى شناخته مىشود. بر

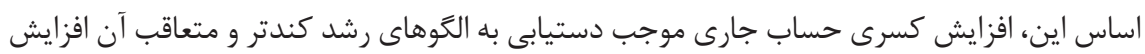
كسرى بودجه دولت مىشود (Algieri, 2013). رشد اقتصادى يايين نهتنها موجب افزايش هزينههاى

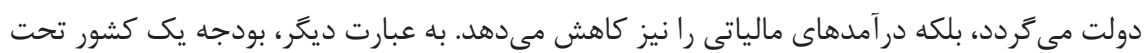
تاثير جريانهاى عظيم سرمايه يا انباشت بدهى قرار مى ميرد كه اين امر در نهايت به كسرى بردير بودجه آن كشور منجر مىشود (Baharumshah et al., 2006). ارتباط بازخورد: حالت ديخر، وجود ارتباط متقابل بين دو كسرى است. براى مثال، همبستكى زياد

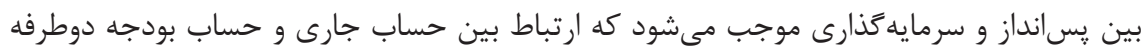
باشد (Algieri, 2013). همجنين، مى توان استدلال نمود كه افزايش كسرى بودجه دولت در شرايط ثابت بودن نرخ ارز و نرخ بهره، و نبود ورود و خروج سرمايه با افزايش تقاضا، كسرى حساب جارى را تشديد مى كند. با تامين كسرى بودجه از مسير سيستم بانكى، يايه يولى و سطح قيمتها برها افزايش

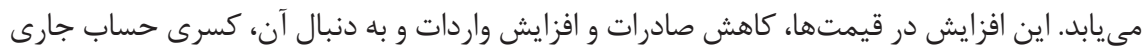
را به دنبال خواهد داشت (زوارئيان كجومثقالى، (9 ||). در اين حالت، كاهش كسرى بودجه براى بهتر شدن وضعيت حساب جارى كافى نيست و لازم است كه به سياستهاى ارزى، تعيين نرخ بهره، و سياستهاى بهبود صادرات توجه شود (Xie \& Chen, 2014). ديدكًاه بينزمانى ريكاردويى: احتمال نبود رابطه مشخص بين كسرى بودجه و كسرى حساب

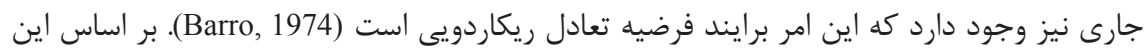
فرضيه، كسرى حساب جارى و كسرى بودجه با يكديكر مرتبط نيستند، زيرا فعاليتهاى مالى دولت

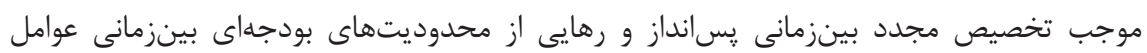

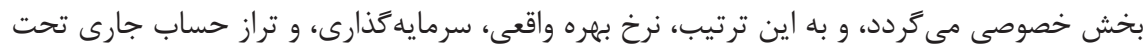

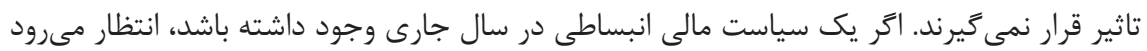

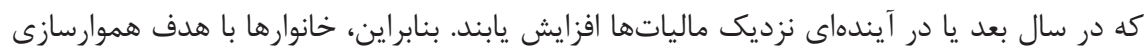

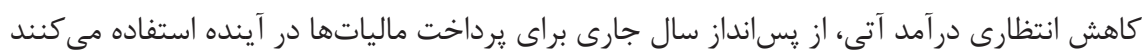

.(Vamvoukas, 1999; Lau \& Baharumshah, 2006; Algieri, 2013) 


\section{واكرايى دوكانه}

در ادبيات نظرى، دو الگُ براى تشريح پديده واگرايى دوگانه وجود دارد. الكوى رشد تصادفى يكبخشى استاندارد و الكَوى دو كشورى با قيمتهاى جسبنده. الكَوى دو كشورى با قيمتهاى

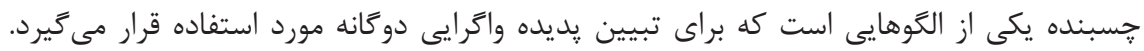
افزايش دائمى مخارج دولت باعث بهبود حساب جارى مىشود. جنانجه مخارج دولت به صورت دائمى افزايش يابد، اثر ريكاردويى به كاهش يكبهيك در مصرف منجر مىشود و حساب جارى بدون تغيير

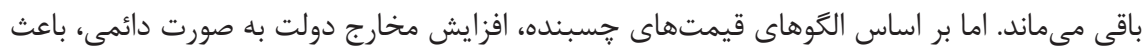
افزايش توليد (تقاضا) در كوتاهمدت مىشود (اين افزايش توليد از سمت تقاضا صورت مى كيرد). بنابراين، همزمان با يكسانسازى مصرف توسط مصرفكنندگان در اثر كاهش توليد خالص در طول

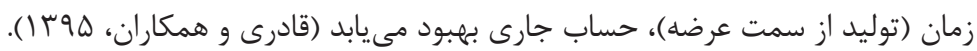

كسرى حساب جارى در كشور هاى صادر كننده نفت

نوسانهاى قيمت نفت اصلىترين منبع نوسانهاى اقتصادى كشورهاى توليدكننده نفت است. افزايش ناگمهانى قيمت نفت يس از سال سوا1 اثرهاى مهمى بر اقتصاد كشورهاى صادركننده نفت كذاشت، بهطورى كه در اين دوره درآمدهاى ارزى حاصل از فروش نفت به شدت افزايش يافت و و باعث رشد سريع قيمتها، نرخهاى دستمزد، و واردات در اين كشورها شد. رشد بخش نفت به عنوان

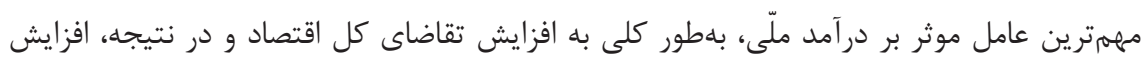

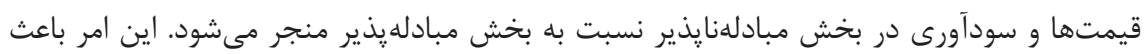

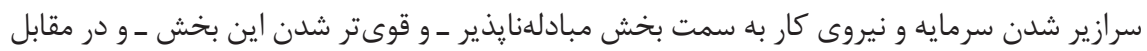
ضعيف شدن بخش مبادلهيذير اغلب اقتصادهاى تكمحصولى مىشود (عصارى آرانى و همكاران،

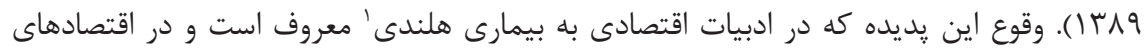

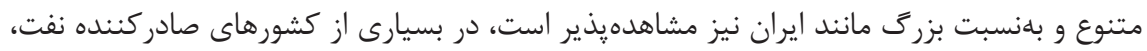

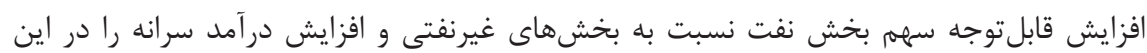

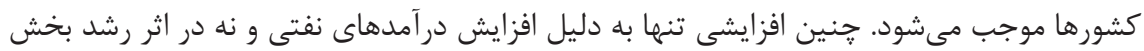


واقعى اقتصاد رخ مى دهد و بىتعادل هايى را در بخشهاى مختلف اين اقتصادها در يى دارد. يكى از متغيرهاى مههم اقتصادى كه به تراز خارجى اين كشورها مربوط مىشود، حساب جارى تراز يرداختهاست كه نشاندهنده معاملههاى اقتصادى بين كشورهاست. افزايش كسرى حساب جارى در اقتصاد كشورهاى مصرفكننده نفت يديدهاى است كه بيشتر در اثر افزايش قيمت نفت ايجاد

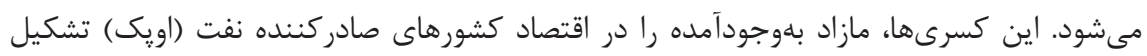

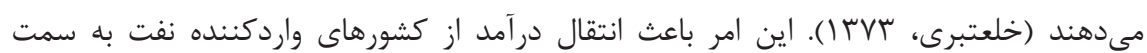
كشورهاى صادركننده، از طريق تغيير در رابطه مبادله مىشود و درآمد حقيقى كشورهاى صادركننده

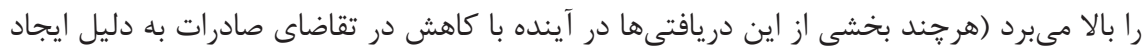

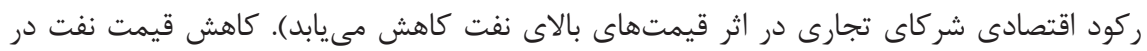

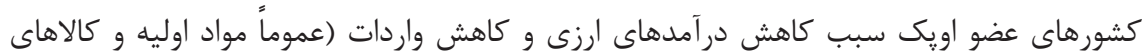
واسطهاى) مىشود، افت شديد توليد را در يى دارد و با توجه به ويزگى اقتصادى اين كشورها، ركود تورمى وكاهش عرضه را در اقتصاد اين كشورها موجب مىشود. از طرفى ديكر، با افزايش قيمت

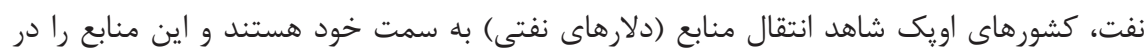
راه سرمايهَذارى در كشورهاى مصرفكننده يا واردات از اين كشورها مصرف مى كنند، بلطورى كه

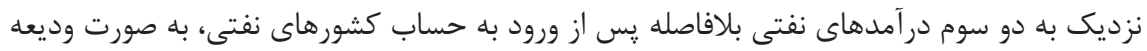

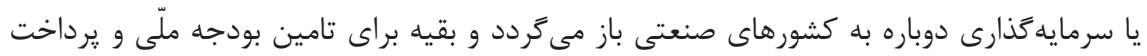
بهاى واردات از اين كشورها، از قبيل خريد تجهيزات، خدمات يا مواد مصرفى (اغلب از آمريكا، اروياى غربى، و زاين) مصرف مىشود (سركيس، سوب (I).

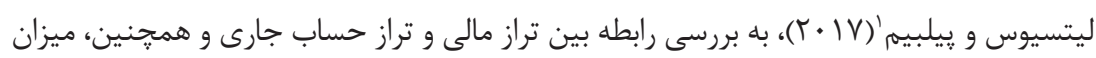
سرمايهَذارى مرتبط با كسرىهاى بزرى حساب جارى در كشورهاى يونان، يرتغال، و اسيانيا با استفاده از

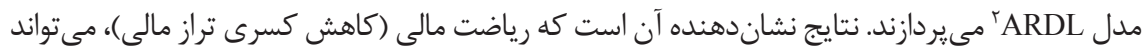
به اين كشورها براى كاهش كسرى حساب جارى كمك كند و قدرت رقابتيذيرى را در اين كشورها حفظ

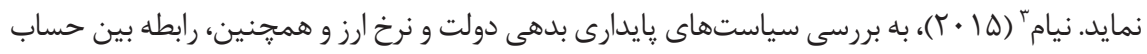

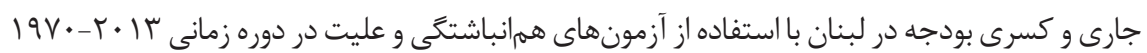
مى يردازد. نتايج نشان مى دهد كه در كوتامدت بين كسرى بودجه و كسرى حساب جارى رابطه عليت

1. Litsios \& Pilbeam

2. Autoregressive Distributed Lag

3. Neaime 
يكىطرفه وجود دارد كه نشان مىدهد افزايش كسرى بودجه باعث افزايش كسرى حساب جارى و بدهى (خى

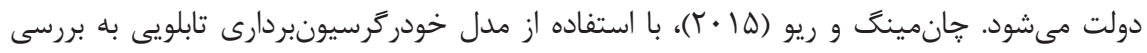

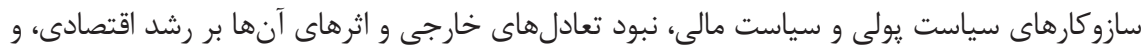

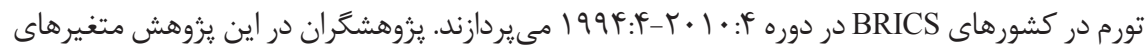
نرخ بهره كوتاهمدت و كسرى بودجه را براى ارزيابى سازوكارهاى سياستهاى يولى و مالى بكار مىبرند. نتايج نشاندهنده اثرهاى معنادار شوك يولى بر رشد اقتصادى است، اما اثر سياستهاى مالى ضعيفتر بردي

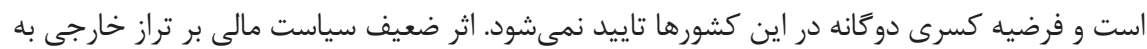

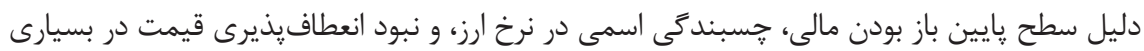

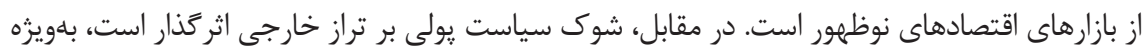

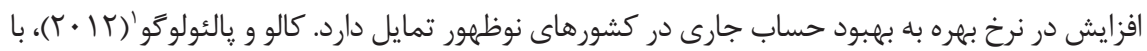

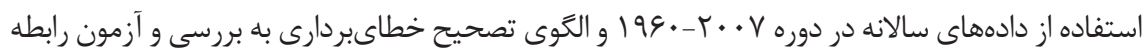
علّى بين كسرى حساب جارى و كسرى بودجه براى كشور يونان مى يردازد. نتايج يزّوهش نشاندهن دهنده

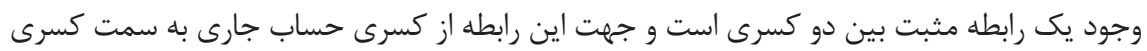

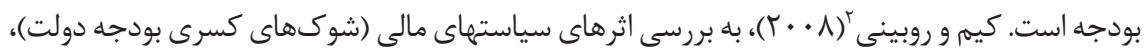

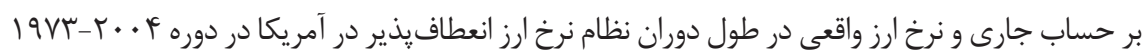

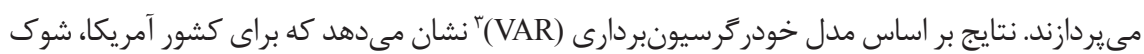

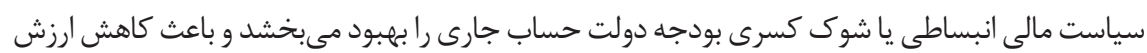

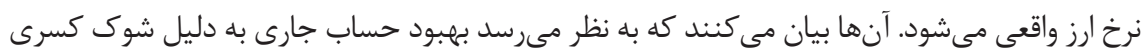

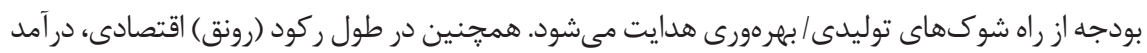

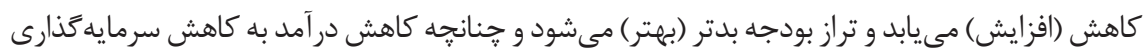

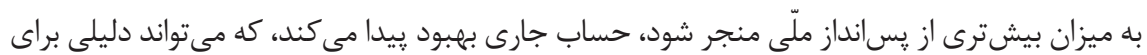
توضيح اين موضوع باشد كه جرا با بدتر شدن كسرى بودجه، كسرى حساب جارى درى در آمريكا بهبود

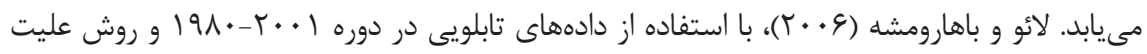

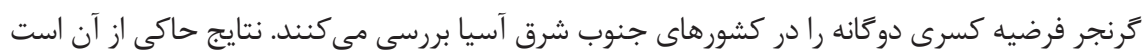
كه كسرى بودجه علت كسرى حساب جارى در اين كشورهاست.

1. Kalou \& Paleologou

2. Kim \& Roubini

3. Vector Autoregression 
قادرى و همكاران (هوس()، با استفاده از الگوى خودرگرسيونبردارى و توابع واكنش ضربهاى

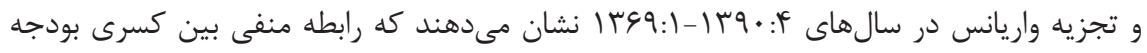
و كسرى حساب جارى در ايران وجود دارد. به عبارت ديگر، پيديده واگرايى دوگانه در اقتصاد ايران تاييد مىشود. از طرفى، در هر دو حالت تاثير تكانه درآمد و مخارج دولت بر اجزاى حساب جارى،

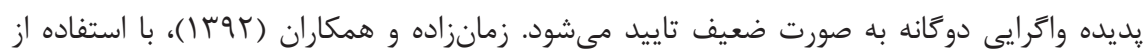

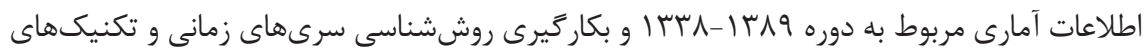
همجمعى در قالب مدلهاى تصحيح خطاىبردارى (VECM)'، به بررسى تاثير كسرى بودجه مالياتى

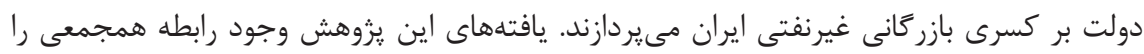

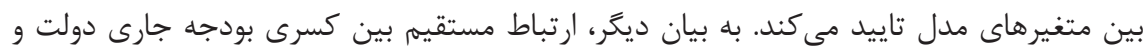

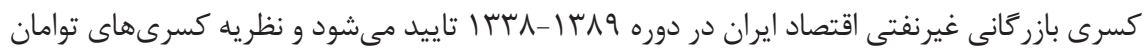

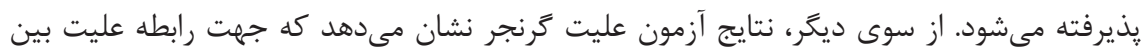

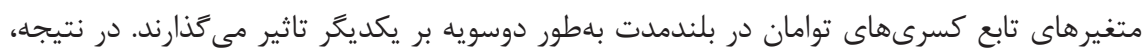

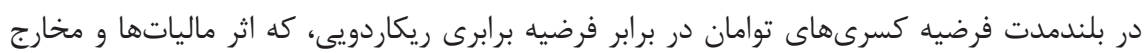
دولت را بر متغيرهاى اقتصادى و كسرى بازركانى كشور بىاثر مىداند، يذيرفته مىشود. زوارئيان

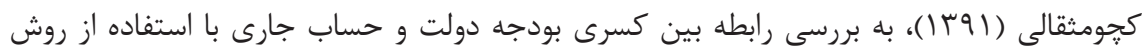

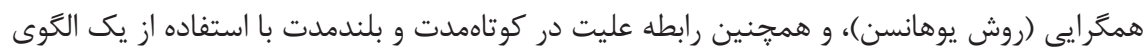

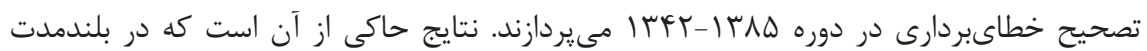
رابطه همجمعى بين كسرى بودجه و كسرى حساب جارى وجود دارد. همجنين، وجود رابطه عليت

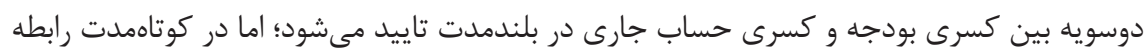

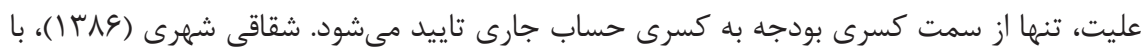

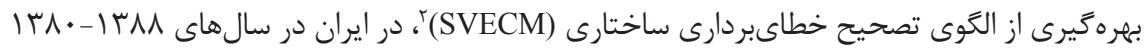
نشان مى دهد كه نتايج بلندمدت براى اجراى سياست كاهش ارزش يول داخلى بردي براى كسرى حسى حساب

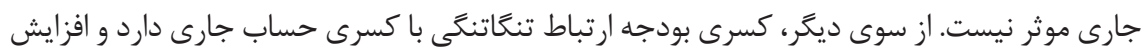

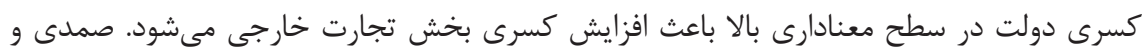

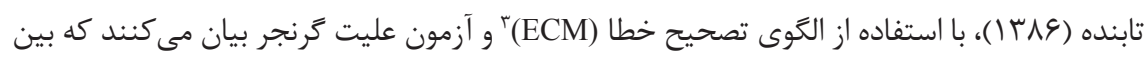

1. Vector Error Correction Model

2. Structural Vector Error Correction Model

3. Error Correction Method 
مخارج دولت و درآمدهاى آن با معيارهاى متفاوت، هيج رابطئ تعادلى بلندمدتى وجود ندارد. اما در

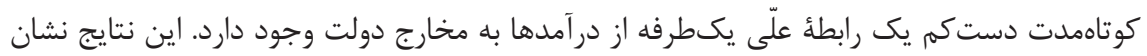

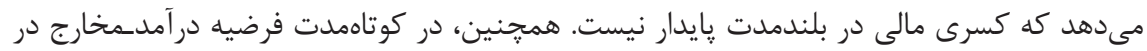
اقتصاد ايران تاييد مىشود. به عبارت ديخر، دولت هزينههاى خود را بر اساس در آمد كسبشده ديد تنظيم

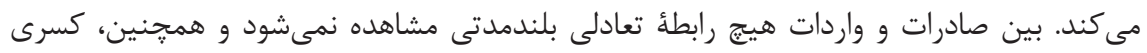
خارجى يايدار نيست. بين نسبت كسرى بودجه و كسرى تجارى به GDP رابطةٔ تعادلى بلندمدت وجود ندارد. نتيجه بادستآمده، از فرضيه برابرى ريكاردويى در بلندمدت تبعيت مى كند. يعنى در بلندمدت

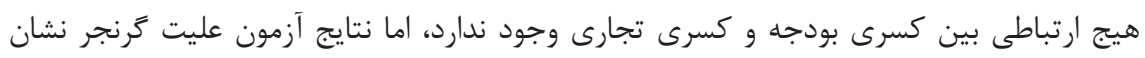

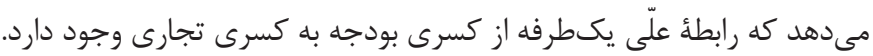

روش

تصريح الكو

در اين يزوهش، اثرهاى سياستهاى يولى و مالى بر كسرى حساب جارى در كشورهاى منتخب .

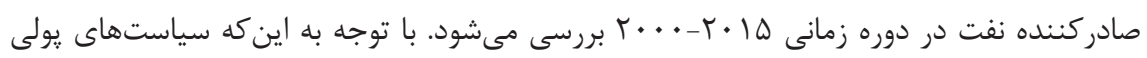
و مالى در ماهيت به يكديگر وابسته هستند، تكانهاى سياست يولى و مالى، همزمان در الكَ در

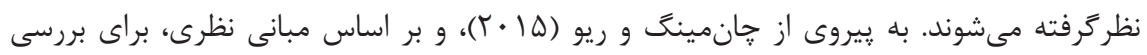

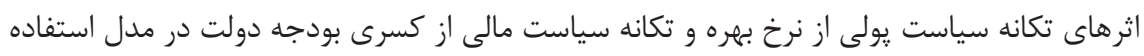

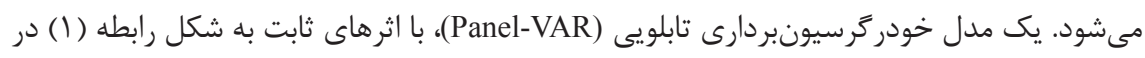
نظر

$Z_{i t}=\varphi_{0}+\sum_{j=1}^{p} H_{j} Z_{i t-j}+\Gamma_{i}+\varepsilon_{i t}$

كه در آن

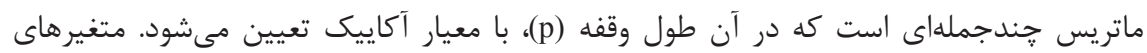

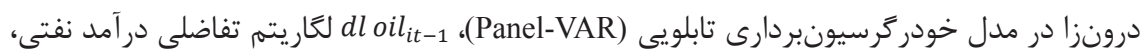

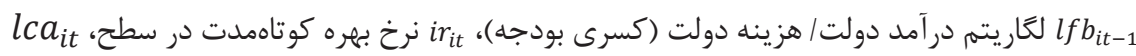
لكاريتم نسبت واردات/صادرات (حساب جارى)، dlgdpit-1 لعاريتم تفاضلى توليد ناخالص داخلى، و و 
lfb bit-1 لكَاريتم تفاضلى نرخ ارز حقيقى هستند. بنابراين، بردار $Z_{i t}=\left[l c a_{i t}, d l g d p_{i t}, d l o i l_{i t}, l f b_{i t}, i r_{i t}, d l e_{i t}\right]$

$$
\text { بنابراين، فرم خلاصهشده الكَىى حساب جارى به صورت الكَى (أ) تصريح مىشود: }
$$

$$
\begin{aligned}
l c a_{i t}= & \alpha_{0}+\gamma l c a_{i t-1}+\lambda d l g d p_{i t-1}+\phi d l o i l_{i t-1}+\rho l f b_{i t-1} \\
& +\kappa i r_{i t-1}+\theta d l e_{i t-1}+\eta_{i}+\varepsilon_{i t}^{c a}
\end{aligned}
$$

مدل VAR بيشتر با مسئله سازگارى نظرى همراه مىشود، اخرخه اين ابزار موثر براى بررسى واكنش يوياى سيسته به شوكها بدون تحميل قيدهاى شناسايى نيز قوى است. اقتصاددانان براى

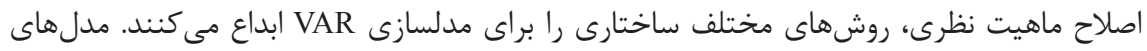

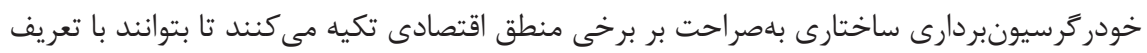

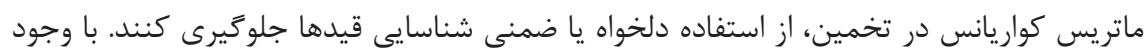
اين، مدل هاى خودر كرسيونبردارى ساختارى (SVAR)، نيز مورد انتقاد قرار مى ميرند. فاوست و ليير'

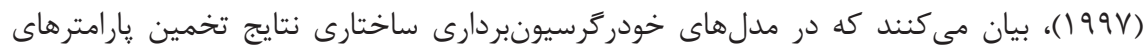

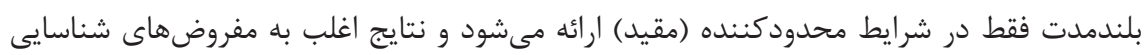
حساس هستند. در اين يزوهش، تحميل يك رابطه بلندمدت حالت پايدار براى كشورهاى صادركننده نفت ممكن است واقعبينانه نباشد، زيرا اين كشورها داراى مسيرهاى رشد مختلف هستند و الكوهاى

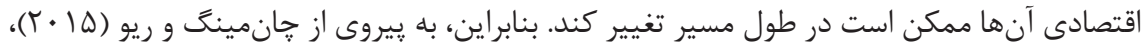

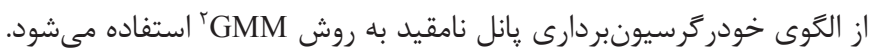

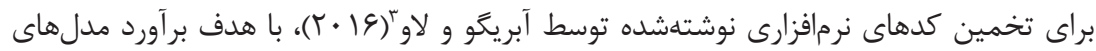

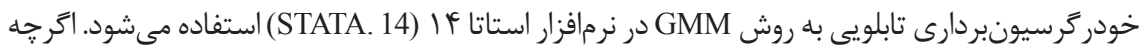
در مدلهاى خودركرسيونبردارى بيشتر حالت سرى زمانى يا دادهاى تابلويى دشوار است، و ضرايب تخمينزدهشده با توجه به ماهيت بىنظمى كه دارند تفسير مىشوند اما برخى روابط ارزشمند وجود دارند كه بايد مورد بررسى قرار گَيرند. (Chunming \& Ruo, 2015).

1. Faust \& Leeper

2. Generalized Method of Moments

3. Abrigo \& Love 


\section{soosl}

متغير درآمد نفتى از مجلههاى آمارى اويك، متغيرهاى توليد ناخالص داخلى و نرخ ارز واقعى از سايت

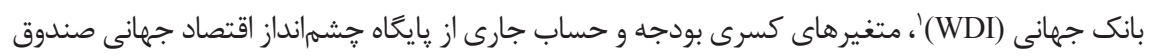

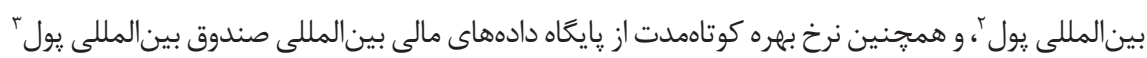
استخر اج مى شوند. كشورهاى منتخب صادر كننده نفت در اين يزوهش شامل الجزاير، كلمبيا، اكوادور، كابن،

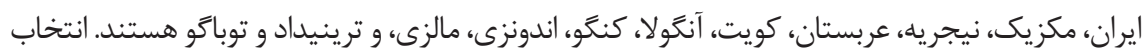

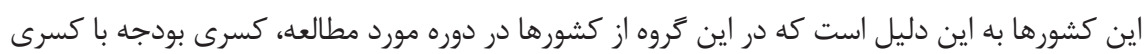

حساب جارى همسوست، و همجنين درآمدهاى حاصل از صادرات نفت براى اين كشورها فزاينده است.

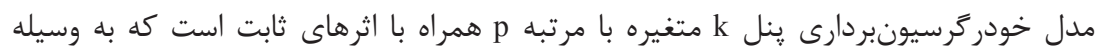
سيستم معادله هاى خطى نشان داده مىشود.

$Y_{i t}=Y_{i t-1} A_{1}+Y_{i t-2} A_{2}+\cdots+Y_{i t-p+1} A_{p-1}+Y_{i t-p} A_{p}+X_{i t} B+u_{i}+e_{i t}$ $i \in\{1,2, \ldots, N\}, t \in\{1,2, \ldots, T i\}$

$e_{i t} u_{i}$ و بردار (×K $Y_{i t}$ بلهترتيب بردارهاى (k × 1) اثرهاى ثابت خاص متغير وابسته و خطاهاى ويزه هستند. ماتريسهاى B( $\mathrm{B}(1 \times K)$ يارامترهايى هستند كه بايد تخمين زده شوند.

$E\left[e_{i t}\right]=0, E\left[e_{i t}^{\prime} e_{i t}\right]=\Sigma$

$E\left[e_{i t}^{\prime} e_{i s}\right]=0 \quad t>s$ براى همئ

يارامترهاى بالا ممكن است باطور مشترك همراه با اثرهاى ثابت يا بهطور مستقل از اثرهاى ثابت

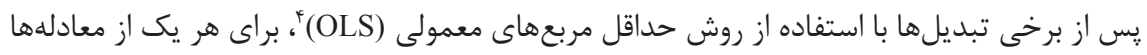

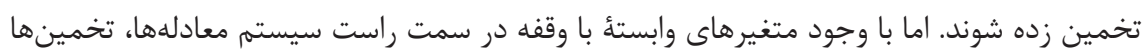
حتى با N بزرى تورشدار خواهند بود (Abrigo \& love, 2016).

1. World Development Indicators

2. World Economic Outlook (WEO)- IMF

3. International Financial Statistics (IFS)- IMF

4. Ordinary Least Squares 


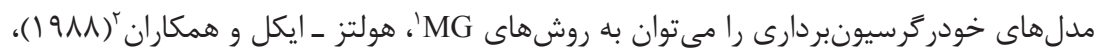

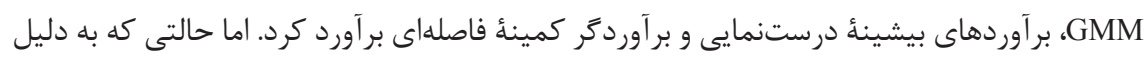

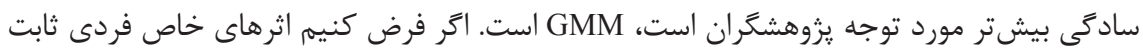
: $a_{i}^{*}$

$$
\phi(L) y_{i t}=y_{i t}-\phi_{1} y_{i, t-1}-\cdots-\phi_{p} y_{i, t-p}=\alpha_{i}^{*}+E_{i r}
$$

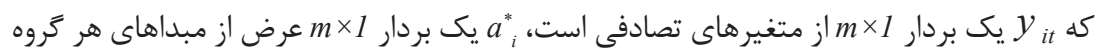

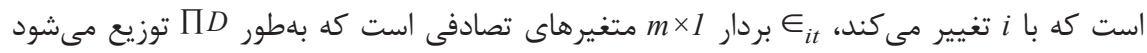
و ميانگَين آن صفر است و ماتريس كوواريانس آن $\Omega$ است،

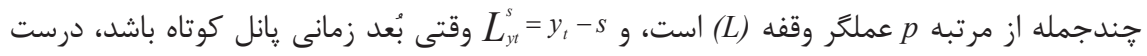
مثل حالت تكمعادله اثر ثابت مدل پانل ديتا، مسئله كلاسيك پارامترهاى مبهرهم و زايد، و و مسئله

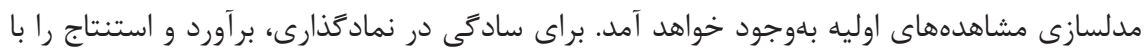

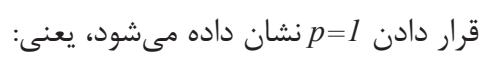

$(1-\phi L)\left(y_{i t}-\eta_{i}-\delta_{t}\right)=\epsilon_{i t}$

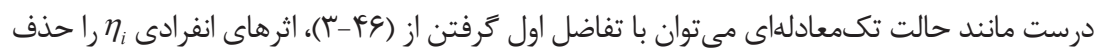

$$
\Delta y_{i t}-\delta=\phi\left(\Delta y_{i, t-1}-\delta\right)+\Delta \in_{i t}
$$

$\left.E\left\{\left[\Delta y_{i t}-\delta-\phi \Delta y_{1, t-1}-\delta\right) q_{i t}^{\prime}\right]\right\}=0$

بنابراين، شرايط عمود بودن عبارت خواهد بود از:

$$
\begin{aligned}
& \left.E\left\{\left[\Delta y_{i t}-\delta-\phi \Delta y_{1, t-1}-\delta\right) q_{i t}\right]\right\}=0 \\
& q_{1}+1\left(1, y_{i}^{\prime}, \ldots y_{i, i-2}^{\prime}\right)^{\prime}
\end{aligned}
$$

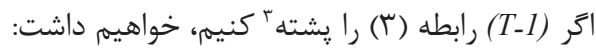

1. Mean Group

3. Stack 
$S_{i}=R . \Lambda+E_{i}$

$S_{i}=\left(\Delta y_{i t}, \Delta y_{i t}, \ldots, \Delta y_{i t}\right)^{\prime}, E_{i}=\left(\Delta E_{i t}, \ldots, \Delta E_{i t}\right)^{\prime}$

$R_{i}=\left(S_{i,-1}, e_{T-1}\right), S_{i,-1}=\left(\Delta y_{i 1}, \ldots, \Delta y_{i T}\right)^{\prime}$,

$\Lambda=\left(\phi, a_{1}\right), a_{1}=\left(I_{m}-\phi\right) \delta$

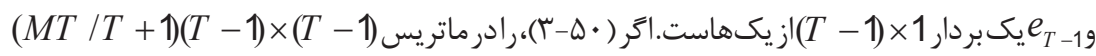
قطرى بلوكى متغيرهاى ابزارى زير ضرب كنيه:

$Q_{i}=\left[\begin{array}{cccc}q_{i 2} & & & 0 \\ & q_{i 3} & & \\ & & \cdot & \\ 0 & & & q_{i T}\end{array}\right]$

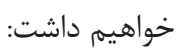

$Q_{i} S_{i}=Q_{i} R_{i} \Lambda+Q_{i} E_{i}$

كه ترانهاده آن به شكل بردارى عبارت خواهد بود از:

$\left(Q_{i} \otimes I_{m}\right) \operatorname{vec}\left(S_{i}^{\prime}\right)=\left(Q_{i} R_{i} \otimes I_{m}\right) \lambda+\left(Q_{i} \otimes I_{m}\right) \operatorname{vec}\left(E_{i}^{\prime}\right)$

عملكَرى هستند كه يك ماتريس را با קيدن ستونهاى آن در زير هم به

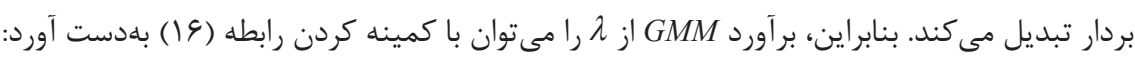

$\left.\left[\sum_{i=1}^{M}\left(Q_{i} \otimes I_{m}\right) \operatorname{vec}\left(S_{i}^{\prime}\right)-\left(Q_{1} R_{i} \otimes I_{m}\right) \lambda\right)\right]^{\prime}$

$\times\left[\sum_{i=1}^{N}\left(Q_{i} \otimes I_{m}\right) \sum\left(Q_{i} \otimes I_{m}\right)^{)}\right]^{-1}$

$\left.\times\left[\sum_{i=1}^{N}\left(Q_{i} \otimes I_{m}\right) \operatorname{vec}\left(S_{i}^{\prime}\right)-\left(Q_{i} R_{1} \otimes I_{m}\right) \lambda\right)\right]$ 


$$
\sum=\left[\begin{array}{ccccc}
2 \Omega & -\Omega & . & \ldots & . \\
-\Omega & 2 \Omega & -\Omega & \ldots & . \\
\cdot & -\Omega & 2 \Omega & -\Omega & . \\
\cdot & \cdot & \cdot & . & \cdot \\
: & \vdots & \vdots & \vdots & \vdots \\
\cdot & . & . & \ldots & 2 \Omega
\end{array}\right]
$$

$$
\text { شرايط گشتاورى كه براى برآورد } \Omega \text { لازم است، عبارت است از: }
$$

$E\left\{\left[\Delta y_{i t}-\delta-\phi\left(\Delta y_{1, t-1}-\delta\right)\right]\left[\Delta y_{i t}-\delta-\phi\left(\Delta y_{i, t-1}-\delta\right)\right]^{\prime}-2 \Omega\right\}=0$

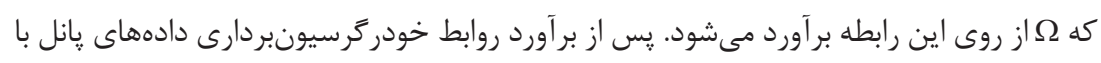

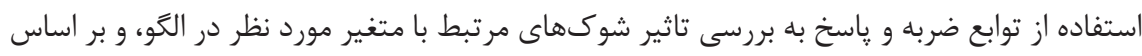

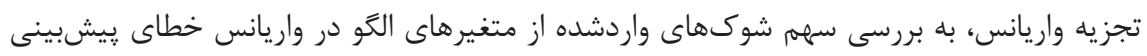

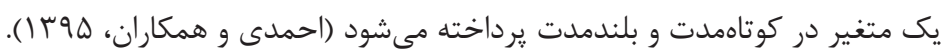

\section{توابع واكنش ضربه در مدل P-VAR}

بدون تغيير در كليت، متغيرهاى برونزا را در نمادگذارى حذف مى كنيم و بر ساختار خودرگرسيون

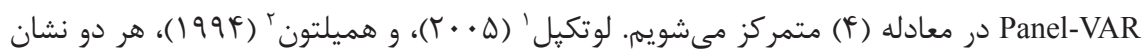

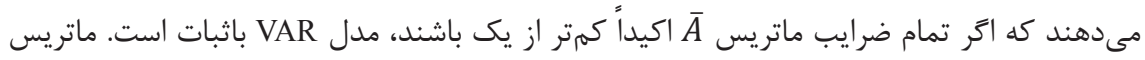
$\bar{A}=\left[\begin{array}{ccccc}A_{1} & A_{2} & \cdots & A_{p} & A_{P-1} \\ I_{k} & 0_{k} & \cdots & 0_{k} & 0_{k} \\ 0_{k} & I_{k} & \cdots & 0_{k} & 0_{k} \\ \vdots & \vdots & \ddots & \vdots & \vdots \\ 0_{k} & 0_{k} & \cdots & I_{k} & 0_{k}\end{array}\right]$ A

ثبات نشان مىدهد كه مدل خودرگرسيونبردارى تابلويى معكوس است و يك بردار ميانگين

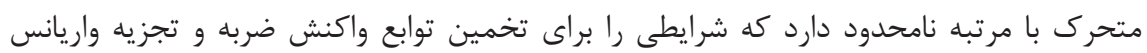




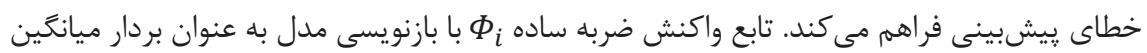
متحرك نامحدود تخمين زده مىشود. $\Phi_{i}=\left\{\begin{array}{lr}I_{k}, & i=0 \\ \sum_{j=1}^{i} \Phi_{t-j} A_{j}, & i=1,2, \ldots\end{array}\right.$

اگر جه توابع واكنش ضربه ساده تفسير علّى را بيان نمى كنند، اما از آنجا كه تغييرهاى e همزمان همبسته هستند، شوك در يك متغير، باعث ايجاد شوك در ساير متغيرها مىشود. فرض رض

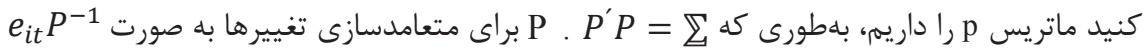
و تبديل يارامترهاى بردار ميانكين متحرك به واكنش ضربه متعامد

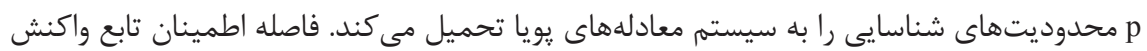

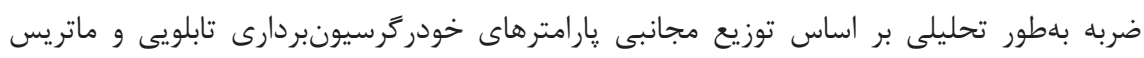

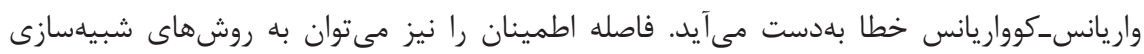
مونت كارلو و نمونه گيرى مجدد بوت استراب تخمين زد (Abrigo \& love, 2016).

\section{تجزيه واريانس خطاى ييشبينى در مدل P-VAR}

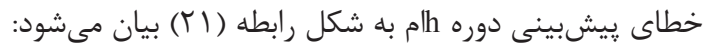

$Y_{i t+h}-E\left[Y_{i t+h}\right]=\sum_{i=0}^{h-1} e_{i(t+h-i)} \Phi_{i}$

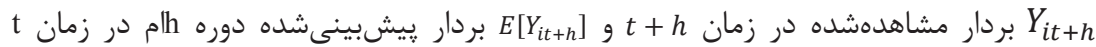

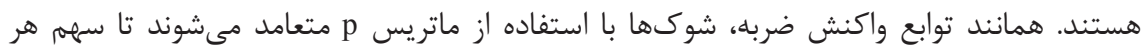
متغير در واريانس خطاى ييشبينى تفكيك شود. شوكهاى متعامد

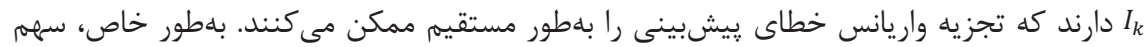

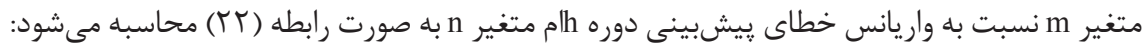
$\sum_{i=0}^{h-1} \theta_{m n}^{2}=\sum_{i=1}^{h-1}\left(i_{n}^{\prime} P \Phi_{i} i_{m}\right)^{2}$ 
is ستون sli

$\sum_{i=0}^{h-1} \theta_{0 n}^{2}=\sum_{i=1}^{h-1} i_{n}^{\prime} \Phi_{i}^{\prime} \sum \Phi_{i} i_{n}$

همانند توابع واكنش ضربه، فواصل اطمينان باطور تحليلى بلدستمى آيند ياباستفادهاز روشهاى مختلف

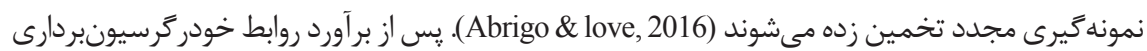
دادههاى يانل مى توان با استفاده از توابع ضربه و ياسخ، به بررسى تاثير شوك هاى مرتبط با متغير مورد نظر

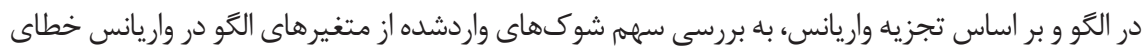

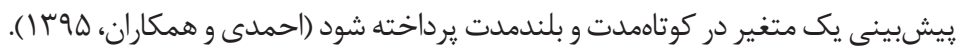

\section{مرورى بر روند نرخ هاى ارز حقيقى}

كشورهاى مكزيك، كابن، الجزاير، اكوادور، عربستان و مالزى روند تقريباً ثابتى در نرخ ارز حقيقى

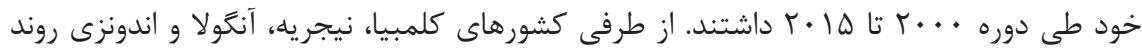

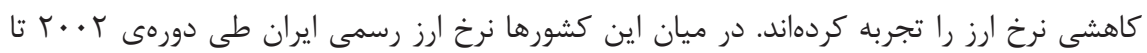

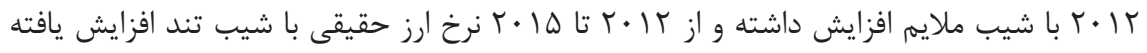

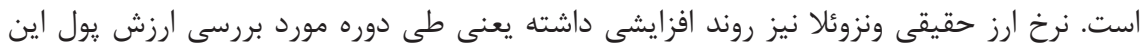

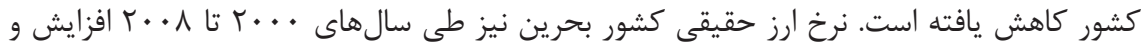

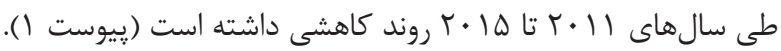

\section{نتايج تجربى}

\section{آزمون ريشه واحد يانل براى مانايى متغيرها}

ִֶنانجه متغيرهاى سرى زمانى مورد استفاده در برآورد پارامترهاى مدل نامانا باشند، احتمال اين كه رگرسيون بهدستآمده كاذب باشد، بسيار بالاست. بنابراين، براى جلوگيرى از ركرسيون كاذب، ابتدا

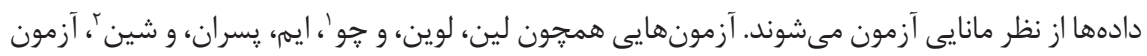


فيشر'، و آزمون هادرى ' از جمله آزمونهاى مانايى در دادهاى تركيبى هستند. نتايج اين آزمونها براى تمام متغيرهاى مدل در جدول ( () نشان داده مىشود. با توجه به نتايج جدول (1)، متغير حساب مردي جارى (Ca) با يكبار تفاضل بهره (ir)، نرخ ارز حقيقى (e)، كسرى بودجه (FB)، و در آمدهاى نفتى (oil) در سطح مانا هستند (I(0)). براى اطمينان از جعلى نبودن نتايج ركرسيون، آزمون همجمعى مورد بررسى قرار مى

جدول ا: بررسى مانايى متغيرها

\begin{tabular}{|c|c|c|c|c|c|c|c|c|}
\hline \multicolumn{2}{|c|}{$\begin{array}{l}\text { آزمون فيشر } \\
\text { (PP-Fisher) }\end{array}$} & \multicolumn{2}{|c|}{$\begin{array}{l}\text { آزمون فيشر } \\
\text { (ADF) }\end{array}$} & \multicolumn{2}{|c|}{$\begin{array}{c}\text { آزمون ايم، يسران، و شين } \\
\text { (IPS) }\end{array}$} & \multicolumn{2}{|c|}{$\begin{array}{l}\text { آزمون لين، لوين و جو } \\
\text { (LLC) }\end{array}$} & \multirow{2}{*}{ متغير - آزمون } \\
\hline احتمال & آماره & احتمال & آماره & احتمال & آماره & احتمال & آماره & \\
\hline$\cdot / V \cdot 99$ & TH/DIFD &.$/ 994 \Delta$ & $1 T / 9.90$ & . $/ 997 V$ & T/FFIIT & - IDVAT & س س & $\mathrm{Ca}$ \\
\hline & $\mid r V / f$ & & $q \pi / V$ & 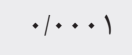 & W & f & $-r / 9 \mid$ & $\mathrm{D}(\mathrm{Ca})$ \\
\hline 1 & GK/VGGG & .1 .94 & $\Delta \cdot / r \wedge \Lambda \mu$ & -- & --- &. & $-r / \Delta \& \wedge \varepsilon \Delta$ & FB \\
\hline .1 & VQ/FYGG & & $\Delta V / I$ & $\cdot 1 \cdot 1$ & - T/.१QTr & . . . & $-r / 9 \wedge q \vee 9$ & ir \\
\hline & $114 / 949$ & $r$ & VF/NFTV & .1 & $-r / 99401$ & $\cdot 1 \cdots$ & $-\Delta / r \wedge<q \Delta$ & gdp \\
\hline$\cdot 1$ & $91 / V I V$. & $\cdot \cdot r|r|$ & $\Delta F / \| F \wedge$. & $\cdot 1 \cdot \cdot 10$ & - K/৭૬Y૬द & ---- & ---- & $\mathrm{e}$ \\
\hline.$/ \ldots$ & $|r r| \cdot c$. &.$/ \ldots$ & VF/Or & $\cdot / \ldots$ & $-F / q \& V I$. & $\cdot / \ldots$ & -G/FVGAF & oil \\
\hline
\end{tabular}

در آزمون همجمعى كائو "، فرضيه صفر مبتنى بر نبود همجمعى بين متغيرهاست. نتايج اين

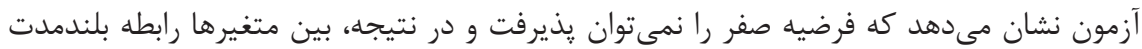
معنادارى وجود دارد.

جدول r: آزمون همجمعى

\begin{tabular}{ccc}
\hline آزمون همجمعى كائو & t آماره \\
\hline
\end{tabular}

1. Fisher-ADF

2. Hadri

3. Kao Cointegration Test 
نتايج تعيين وقفه بهينه مدل در جدول (rآ) نشان داده مىشود. نتايج حاكى از تاييد يك وقفه بهينه

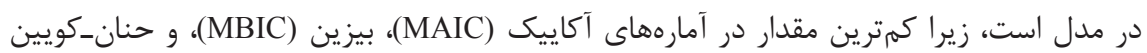
به وقفه يك مربوط مىشود. (MQIC)

جدول r: تعيين وقفه بهينه

\begin{tabular}{|c|c|c|c|c|c|c|}
\hline MQIC & MAIC & MBIC & $\mathbf{J}$ pvalue & $\mathbf{J}$ & CD & Lag \\
\hline$-Y T r / Q Y \cdot r$ & $-99 / V 11 r$ & $-F T V / V \cdot T I$ & משr & $\| \varepsilon / r \wedge \Lambda \Lambda$ &.$/ 9999 \cdot 19$ & 1 \\
\hline 9 & $-V / / \Delta 11<q$ & $-r q \cdot|| V r \mid$ &.$|48| \& 194$ & $V T / F \wedge \wedge \Delta I$ & $. / 999 \vee<91$ & $r$ \\
\hline -VF/TqFre & -rq/ANFEV & $-|r q / r| \Delta$ & . ITTKG. & سKQT/I & - $/ 9 \wedge \Delta 91 \Delta 9$ & r \\
\hline
\end{tabular}

نتايج تخمين مدل در جدول (f) نشان داده مىشود. ضريب درآمدهاى نفتى منفى و معنادار

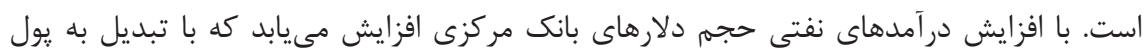
داخلى، بر حجم يول و نقدينكى افزوده مىشود، و سرانجام به افزايش قيمتهاى داخلى دائى و افزايش تقاضاى واردات منجر مىشود. در نتيجه، حساب جارى كاهش يا كسرى حساب جارى افزايش مى يابد.

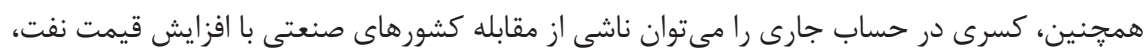
به صورت افزايش قيمت كالاهاى صنعتى دانست. به طوريكه عليرغم افزايش درآ آمدهاى ارزى از از محل صادرات نفت، از آنجا كه كشورهاى منتخب صادركنندهى نفت در اين يزوهش (همكى كشورهاى درحال توسعه نيز هستند)، واردكنندهى عمدهى محصولات نيمهصنعتى و صنعتى از كشورهاى

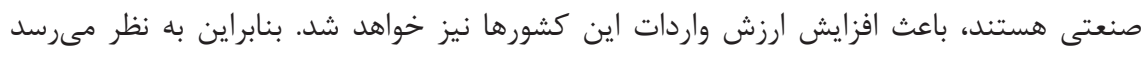

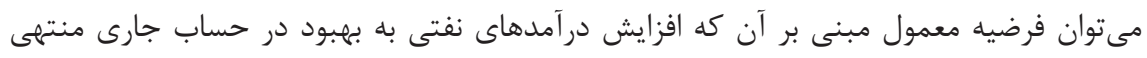

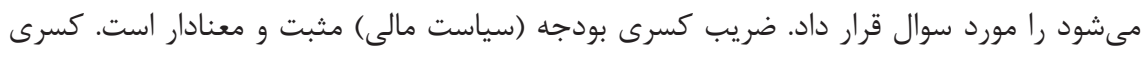

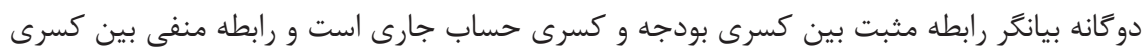

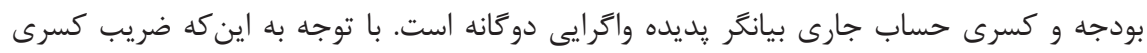

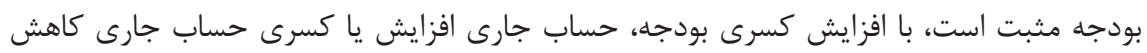

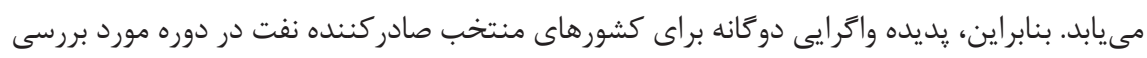

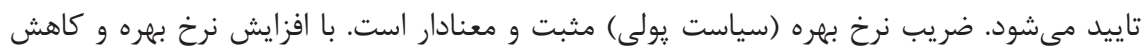

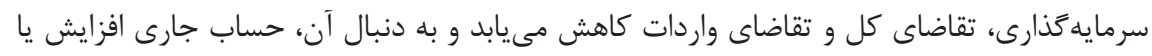


كسرى حساب جارى كاهش مىيابد. ضريب توليد ناخالص داخلى مثبت و معنادار است. با افزايش

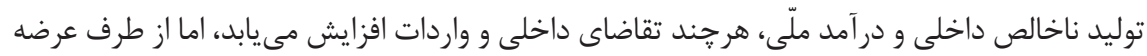
ممكن است توليد كالاهاى جايكزين واردات افزايش يابد، كه باعث افزايش حساب جارى يا كاهش

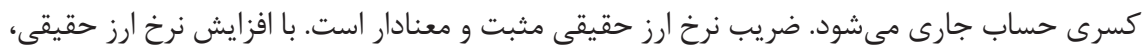

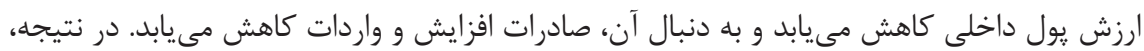
حساب جارى افزايش يا كسرى حساب جارى كاهش مى ديابد.

جدول ب: نتايج تخمين مدل

\begin{tabular}{|c|c|c|c|c|c|c|}
\hline \multicolumn{2}{|c|}{ فاصله اطمينان ه9٪٪ } & \multirow{2}{*}{ احتمال } & \multirow{2}{*}{ 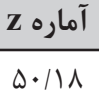 } & \multirow{2}{*}{ انحراف معيار } & \multicolumn{2}{|l|}{ ضريب } \\
\hline 1/.VTrVq & $1 / 1 \Delta 9 \Delta \Delta \mu$ & & & & $1 / 110949$ & $\mathrm{LCa}$ \\
\hline & & & & & & L1 \\
\hline \multirow[t]{2}{*}{$-\cdot 1 \cdot \cdot 1 \vee 99 \Delta$} & $-\cdot|\cdot \cdot f \cdot q|$ & $\cdot 1 \cdot r$ & 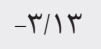 & • 1 . r rFVA & $-\cdot 1 \cdot \cdot 1 \cdot \wedge \mathrm{VA}$ & DLoil \\
\hline & & & & & & L1 \\
\hline \multirow[t]{2}{*}{ - MTrGAII } & - DPFTRAVV & $\cdot 1 \cdots$ & $|\Delta / \wedge|$ & $\cdot 1 \cdot r \cdot \Delta I r \Delta$ & - /FATr人fr & $\mathrm{LFb}$ \\
\hline & & & & & & L1 \\
\hline \multirow[t]{2}{*}{$.1 \cdot 111109$} & $.1 \cdot$ IfAVRF & $\cdot / \cdots$ & Ir/AD & $\cdot 1 \cdot \cdot 994 \cdot V$ & .1.1r.rag & ir \\
\hline & & & & & & L1 \\
\hline \multirow[t]{2}{*}{$\cdot 1 \cdot \cdot \Delta \cdot \cdot \Delta \Delta$} & $\cdot 1 \cdot \Delta 997 \wedge$ & $\cdot / \cdots$ & TI/AT & $\cdot 1 \cdot r \Delta 19$ & $\cdot 1 \cdot \Delta r q q r$ & DLgdp \\
\hline & & & & & & L1 \\
\hline \multirow[t]{2}{*}{$1 / \cdot r \Delta \wedge F \wedge$} & $1 / \Gamma \cdot q r \vee q$ & $\cdot / \cdots$ & $19 / 9 \mathrm{~V}$ & $.1 .99 \cdot 1 \mathrm{fr}$ & $1 / 181111$ & DLe \\
\hline & & & & & & L1 \\
\hline
\end{tabular}

با توجه به نتايج جدول (ه)، عليت گرنجر از طرف درآمدهاى نفتى، نرخ بهره، توليد ناخالص

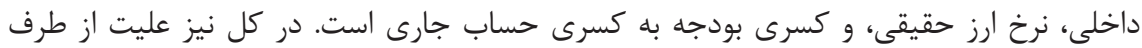
متغيرهاى درونزا به كسرى حساب جارى است. 
جدول ه: عليت كرنجر

\begin{tabular}{|c|c|c|c|}
\hline احتمال & درجه آزادى & آماره & متغير \\
\hline.$/ \cdot r$ & 1 & q/VAr & dloil \\
\hline$\cdot / \cdots$ & 1 & $r \Delta \cdot|\cdot| r \mid$ & $1 \mathrm{Fb}$ \\
\hline$\cdot / \cdots$ & 1 & $191 /$ AFV & ir \\
\hline$\cdot / \cdots$ & 1 & FVGIVTr & dlgdp \\
\hline$\cdot / \cdots$ & 1 & rAV/9DT & dle \\
\hline.$/ \ldots$ & $\Delta$ & $111 / / 99 \wedge$ & All \\
\hline
\end{tabular}

با توجه به نتايج جدول (9)، عليت گرنجر از طرف كسرى حساب جارى به توليد ناخالص داخلى، درآمدهاى نفتى، نرخ ارز حقيقى، و كسرى بودجه وجود دارد، اما عليت از كسرى حساب جارى به نرخ

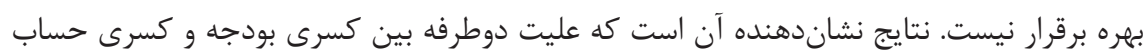
جارى وجود دارد.

جدول ٪: عليت كرنجر

\begin{tabular}{|c|c|c|c|c|c|c|c|c|c|c|}
\hline & dle & dlg & & & ir & IFb & & dl & & متغيير \\
\hline احتمال & آماره د.آ & د.آ احتمال & آماره & آ احتمال & آماره د.آ & د.آ احتمال & آماره & د.آ احتمال & آماره & lca \\
\hline$\cdot / \cdots$ & I $|\wedge V / I K|$ &.$/ \ldots \quad 1$ & $r \cdot N \Delta S \Delta$ & $\cdot / \Delta \Delta$ & $1 \mathrm{r} / \cdot 1 \mathrm{~A}$ & ./.q । & T/ATF &.$\cdots \quad 1$ & $1 r q / \wedge \Delta q$ & \\
\hline
\end{tabular}

توابع واكنش آنى مدل در نمودار (1) نشان داده مىشود. وقوع يك واحد تكانه روى نمودار در توابع واكنش آنى هنگًامى معنادار است كه هر دو مسير معنادارى، اطراف تابع واكنش از محور افقى

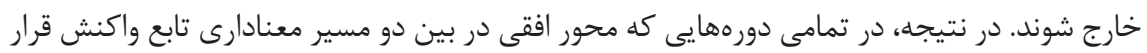
دارد، بيانكر نبود معنادارى تاثير تكانه در آن دوره است (عبدالهى آرانى و همكاران، عهب (1). 

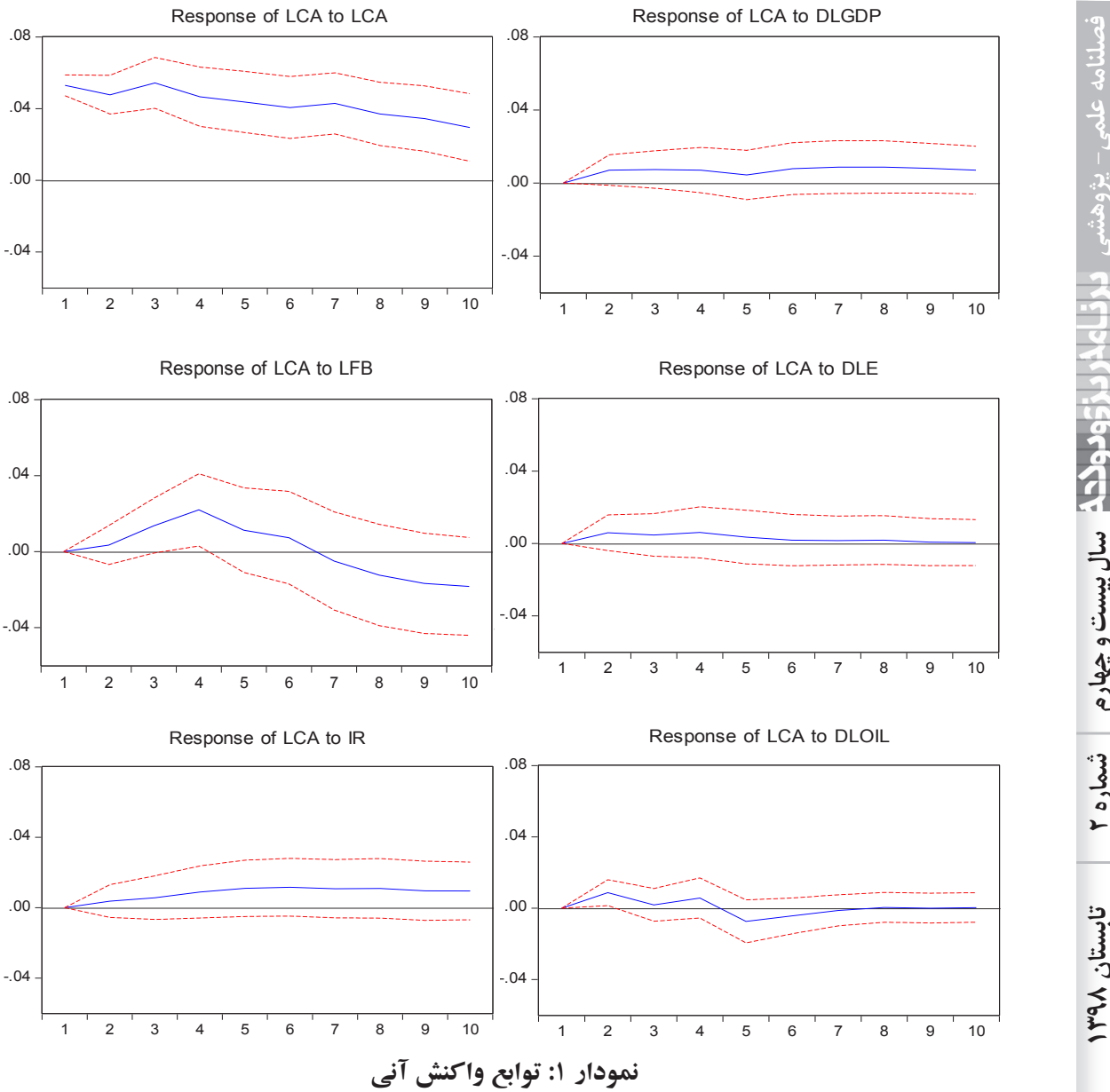

واكنش حساب جارى به كسرى بودجه در كوتاهدت (دورههاى دوم تا جهارم) مثبت و معنادار است. به عبارت ديخر، با افزايش كسرى بودجه، حساب جارى در كوتاهمدت بهبود ميى يابد، يا به نوعى، كسرى حساب جارى كاهش مى يابد. به دليل وجود رابطه منفى بين كسرى بودجه و كسرى حساب

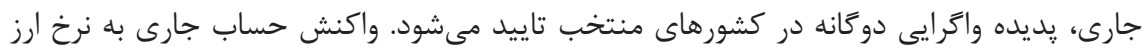
حقيقى مثبت است، اما اين اثر از لحاظ آمارى معنادار نيست و محور افقى در در تمام دورهها دهائ در بين دو مسير معنادارى قرار مى گيرد. اين امر مىتواند به اين دليل باشد كه استفاده از سياستهاى ارزى مئى 
بدون سياستهاى مالى مكمل، اثربخشى لازم را براى بهبود حساب جارى ندارد. به عبارت ديگر، در اين كشورها براى كاهش كسرىهاى تجارت خارجى نمىتوان تنها به سياستهاى ارزى و تغييرهاى

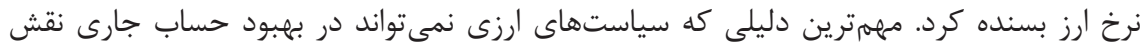
مهرى ايفا كند، ناهمخوانى و ناهماهنكى سياستهاى ارزى با سياستهاى يولى، مالى، و تجارى است.

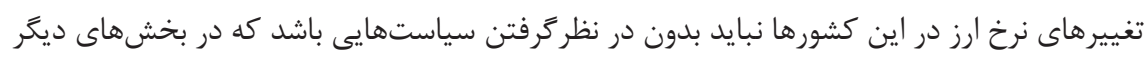

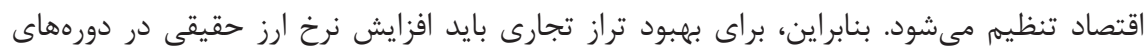
مختلف تداوم داشته باشد و اين تداوم نيز با سياست كاهش كسرىهاى مالى همراه شود. بردي اين نتيجه

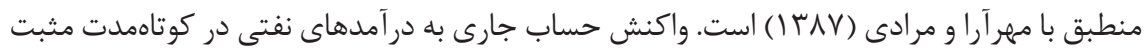

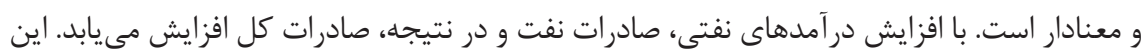

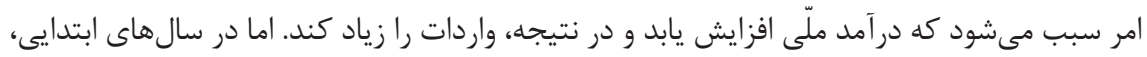
افزايش صادرات از افزايش واردات بيشتر است و سبب ايجاد مازاد حساب جارى مىشود (عصارى

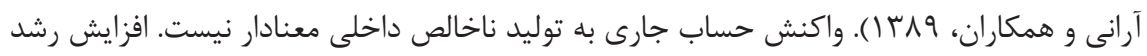

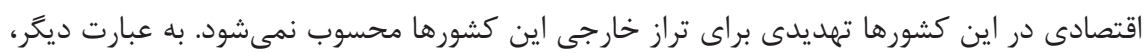
تكانه رشد توليد ناخالص داخلى به اندازه كافى قوى نيست كه بر تراز خارجى اين كشورها اثر بحذارد.

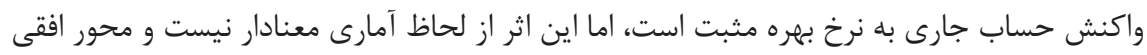

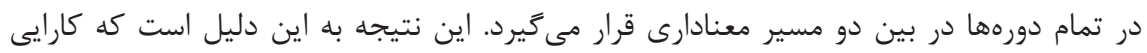

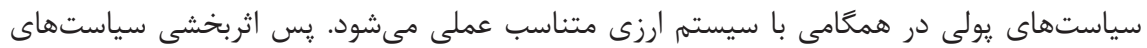
يولى هنًَامى مشاهدهذير است كه سيستم نرخ ارز قادر باشد بخشى از نوسانهاى ناشى از از تغيير

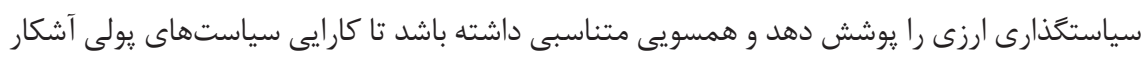

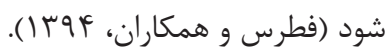
نتايج تحليل تجزيه واريانس در جدول (V) نشان داده مىشود. با توجه به نتايج جدول (V)، در دوره يكم (كوتاهمدت)، · ․

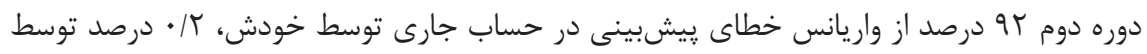

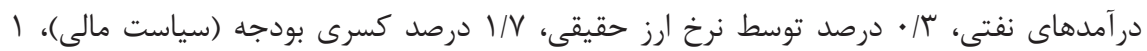

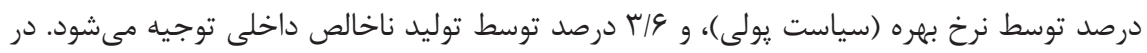
دوره دهم (بلندمدت)، 1/ / • درصد از واريانس خطاى ييشبينى در حساب جارى توسط خودش،

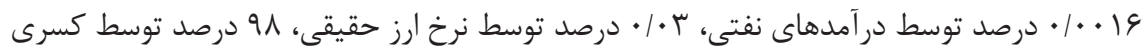


بودجه، V/• درصد توسط نرخ بهره، و ٪/• توسط توليد ناخالص داخلى توضيح داده مىشود. تحليل

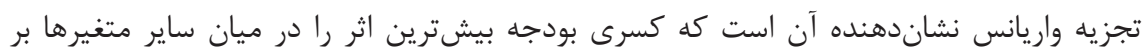
حساب جارى كشورهاى منتخب صادركننده نفت در بلندمدت دارد. يس از آن نيز نرخ بهره و و توليد ناخالص داخلى بيشترين سهمم را در توضيح واريانس خطاى يِيشبينى حساب جارى دارند.

\begin{tabular}{|c|c|c|c|c|c|c|}
\hline ir & dle & dloil & dlgdp & Ifb & lca & دوره \\
\hline$\cdot 1 \cdot \cdot$ & $\cdot 1 \cdot \cdot$ & $\cdot 1 \cdot \cdot$ & $\cdot / \cdot$ & $\cdot 1 \cdot$ & $1 / \cdots$ & 1 \\
\hline$\cdot|\cdot| \cdot r \& \mid r$ & •. •rqVrr & •.・TVYNI & $\cdot / \cdot r G F \Delta \Delta F$ &.$/ \cdot$ IVTATF & 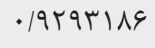 & r \\
\hline$\cdot|\cdot r \&| V \& 9$ & $\cdot \cdot$ rrav & $\cdot|\cdot r| \cdots r$ & $\cdot 1 \cdot 190 \cdot 19$ & - /1. VTFYG & - /VVTDING & $r$ \\
\hline$\cdot 1 \cdot r k q \cdot 9 \Delta$ & $\cdot / \cdot r I V \wedge \Lambda$ & . . VIVTr & $\cdot / \cdot \wedge \vee \curlyvee \wedge \wedge \Delta$ & • MFTTVED & - IDTQFVFF & f \\
\hline$\cdot / \cdot r \Lambda \cdot 1 \cdot 1$ & $\cdot . \cdot 19 \Delta T$ & .1 .11499 & $. / \cdot F V M \| V$ & $\cdot \mid q \psi V \cdot .+\Delta$ & - ITVFAVIA & $\Delta$ \\
\hline $.1 \cdot$ IVTAVF & $.1 . .999$ & $\cdot \cdots \Delta r r V$ & $\cdot / \cdot 191991$ & $\cdot \mid \Lambda \Delta \cdot r g V T$ & . /111ArGD & 4 \\
\hline $.1 .1 .9 V K r$ & $\cdot \cdots r \Delta \Delta s$ & $\cdot|\cdots r| \Lambda$ & $\cdot / \cdot \wedge ৭ r \vee V ~$ & $\cdot / 9 F \cdot r q 4 \lambda$ & $. / \cdot r q 1 \Delta \mid V$ & v \\
\hline$\cdot|\cdot \wedge r \Delta| \Delta$ & . . . rqgr & $\cdot / \cdots \wedge \wedge \vee$ & $\cdot . \cdot \Delta$ AVRr & ./9Vरq1Vq & $\cdot / \cdot I r \wedge V F \Delta$ & $\wedge$ \\
\hline$\cdot \cdot \cdot V \Delta V G F$ & $\cdot \cdots r \| \mid$ & $\cdot / \cdot \cdot r \Delta r$ & •/・r१६•V & 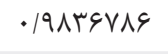 & . . pratra & 9 \\
\hline$\cdot 1 \cdot$ v $\{\&\{1$ & . . . rTVG & $\cdot / \cdots \cdot \mid 9 \Lambda$ & 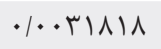 & 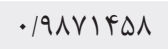 & $\left.\cdot|\cdot| \wedge\right|^{\prime} \wedge \wedge$ & 1. \\
\hline
\end{tabular}

بحث و نتيجه كيرى

اين يزوهش به تحليل اثرهاى سياستهاى يولى و مالى بر كسرى حساب جارى در كشور هاى منتخب

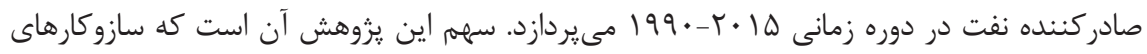

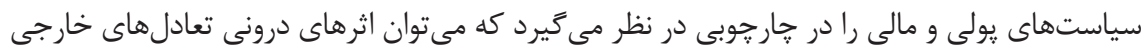

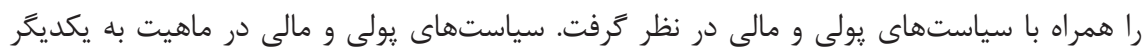

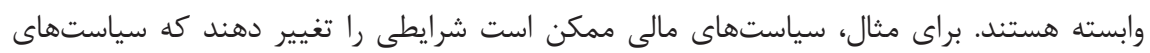

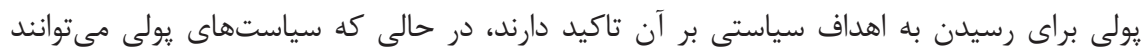

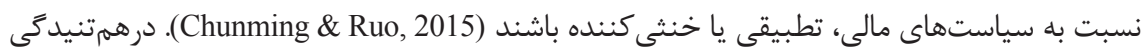
سياستهاى يولى و مالى بهطور اثربخشى كشورهاى صادركننده نفت را تحت تاثير قرار مىدهد، زيرا

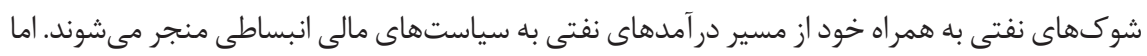


تبديل درآمدهاى ارزى نفت به يول ملّى، افزايش يايه يولى، و در نهايت رشد نقدينكى را سبب مئشود.

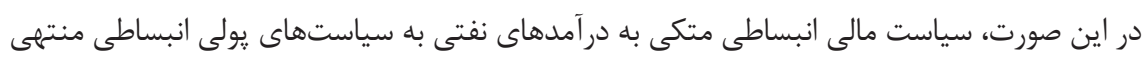

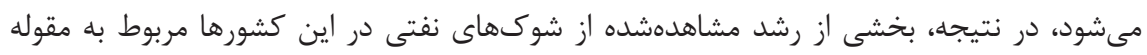
سياست يولى و بخشى مربوط به سياست مالى است.

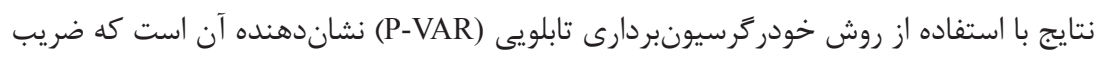

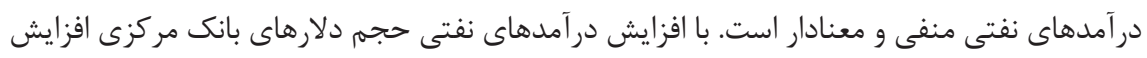

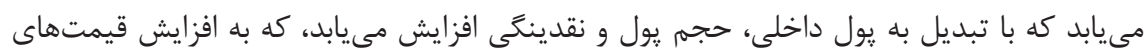

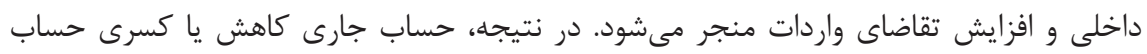

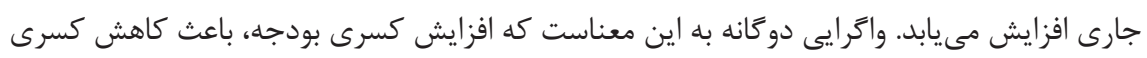

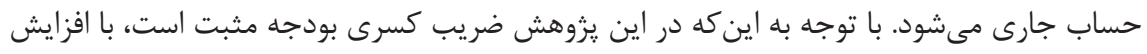

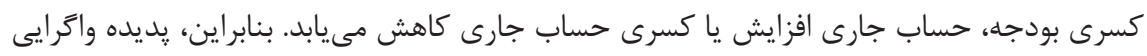

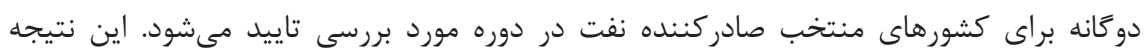

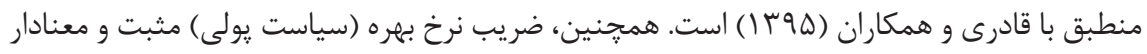

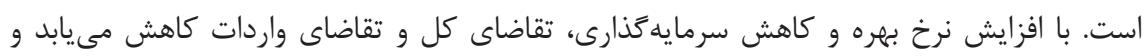

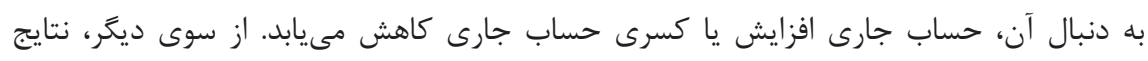

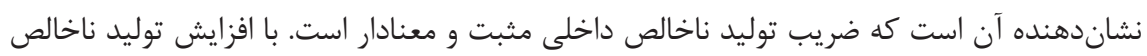

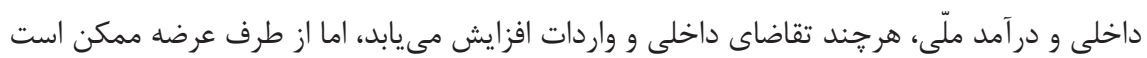

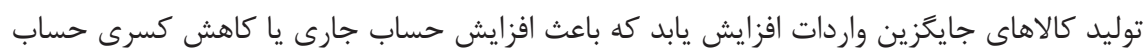

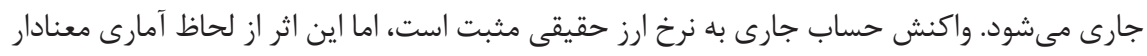

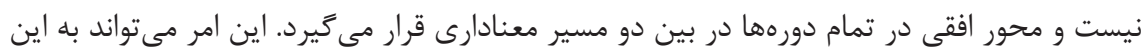

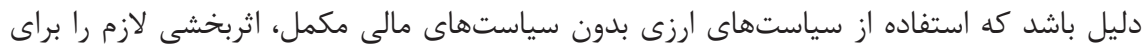

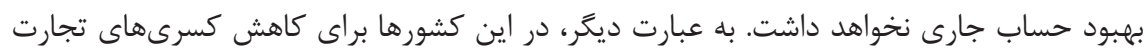

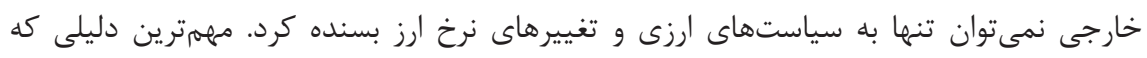

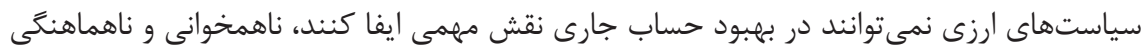

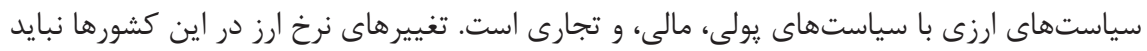

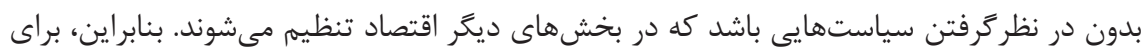

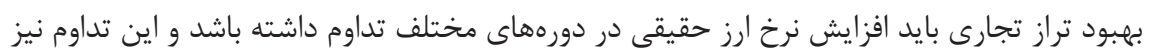


با سياست كاهش كسرىهاى مالى همراه شود. اين نتيجه منطبق با مهرآرا و مرادى (I I ) است.

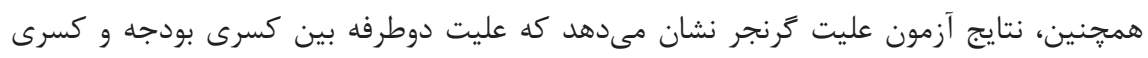
حساب جارى وجود دارد. در ادامه، يِيشنهادهاى اجرايى و يزوهشى در راستاى نتايج يزوهش توصيه مىشود. سياست يولى

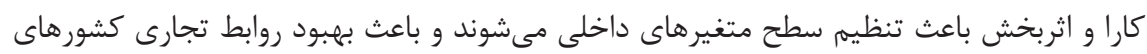
صادر كننده نفت و همسويى با سطح متغيرهاى جهانى مانند نرخ بهره خارجى مىشوند. اين امر يويايى روابط تجارى كشورهاى صادركننده نفت را در عرصه بينالمللى به دنبال دارد، كه لازمه اين امر، ايجاد

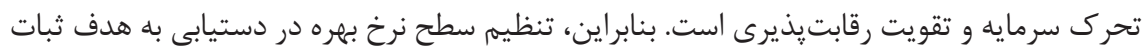

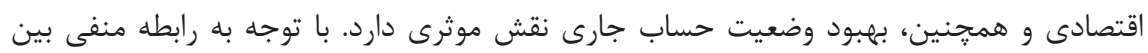
كسرى حساب جارى و كسرى بودجه، جنانجه كشورها در دوره رونق اقدام به افزايش كسرى بودجه نمايند، باعث كاهش كسرى حساب جارى خواهد شد كه به رشد اقتصاد كمك خواهد كرد.

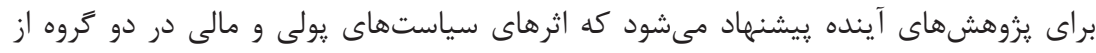

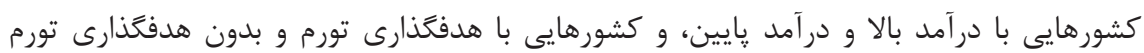
تحليل و مقايسه شوند.

احمدى، على؛ احمدى جشفقانى، حسينعلى، و ابوالحسنى هستيانى، اصغر (9ه (1). تاثير ريسك اعتبارى بر

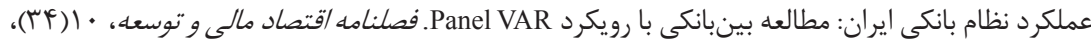

$$
\text { خلعتبرى، فيروزه (سT I I ). مبانى اقتصادى نفت. انتشارات علمى و فرهنكى. }
$$

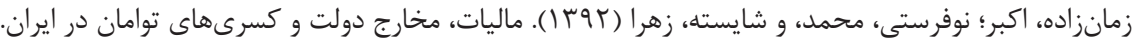

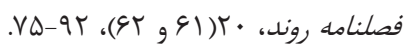

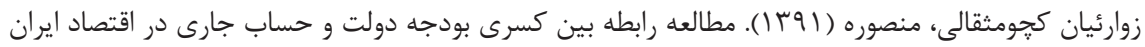

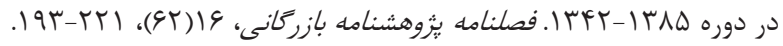

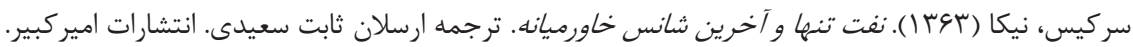




$$
\begin{aligned}
& \text { شقاقى شهرى، وحيد (ع 1 (). بررسى متغيرهاى كلان اقتصادى موثر بر كسرى حساب جارى ايران. جستارهاى }
\end{aligned}
$$

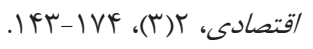

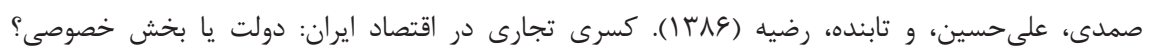

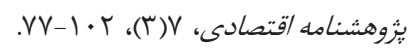

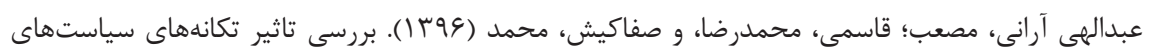

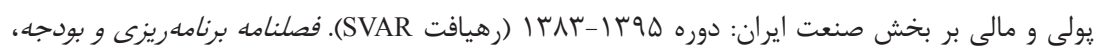

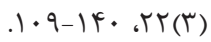

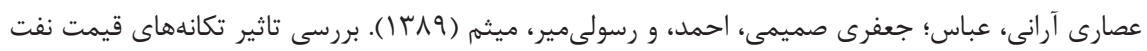

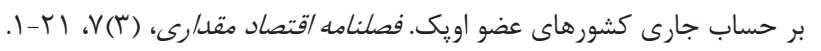

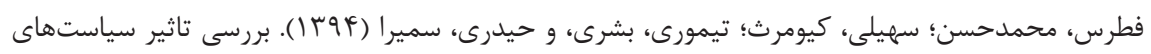

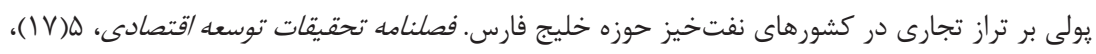

$$
\begin{aligned}
& \text { أب } \\
& \text { قادرى، جعفر؛ صمدى، على حسين، و قادرى ثانى، بتول (هوب1). تاثير تكانه كسرى بودجه بر كسرى حساب }
\end{aligned}
$$

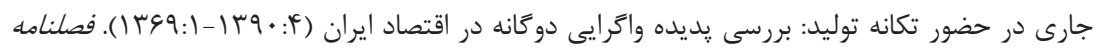

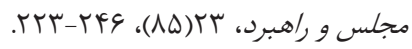

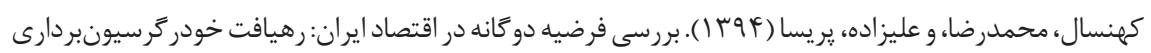

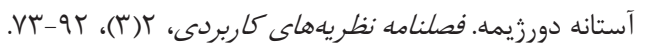

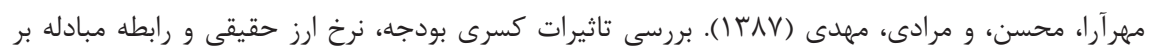

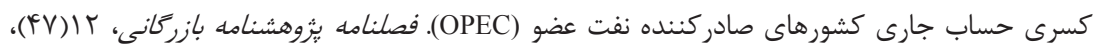

$$
\begin{aligned}
& .|4|-19 V
\end{aligned}
$$

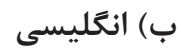

Abrigo, M. R., \& Love, I. (2016). Estimation of Panel Vector Autoregression in Stata. The Stata Journal, 16(3), 778-804.

Algieri, B. (2013). An Empirical Analysis of the Nexus between External Balance and Government Budget Balance: The Case of the GIIPS Countries, Economic Systems, 37(2): 233-253.

Baharumshah, A. Z., Lau, E., \& Khalid, A. M. (2006). Testing Twin Deficits Hypothesis Using VARs and Variance Decomposition. Journal of the Asia Pacific Economy, 11(3), 331-354.

Barro, R. J. (1974). Are Government Bonds Net Wealth? Journal of Political Economy, 82(6), 1095-1117. 
Bartolini, L., \& Lahiri, A. (2006). Twin Deficits, Twenty Years Later. Current Issues in Economics and Finance, 12(7), 1-7.

Chunming, Y., \& Ruo, C. (2015). Policy Transmissions, External Imbalances, and Their Impacts: Cross-Country Evidence from BRICS. China Economic Review, 33(1), 1-24.

Faust, J., \& Leeper, E. M. (1997). When Do Long-Run Identifying Restrictions Give Reliable Results? Journal of Business \& Economic Statistics, 15(3), 345-353.

Hamilton, J. D. (1994). Time Series Analysis (Vol. 2): Princeton New Jersey.

Holtz-Eakin, D., Newey, W., \& Rosen, H. S. (1988). Estimating Vector Autoregressions with Panel Data. Econometrica: Journal of the Econometric Society, 56(6), 1371-1395.

Kalou, S., \& Paleologou, S.-M. (2012). The Twin Deficits Hypothesis: Revisiting an EMU Country. Journal of Policy Modeling, 34(2), 230-241.

Kim, S., \& Roubini, N. (2008). Twin Deficit or Twin Divergence? Fiscal Policy, Current Account, and Real Exchange Rate in the US. Journal of International Economics, 74(2), 362-383.

Lau, E., \& Baharumshah, A. Z. (2006). Twin Deficits Hypothesis in SEACEN Countries: A Panel Data Analysis of Relationships between Public Budget and Current Account Deficits. Applied Econometrics and International Development, 6(2), 213-226.

Litsios, I., \& Pilbeam, K. (2017). An Empirical Analysis of the Nexus between Investment, Fiscal Balances and Current Account Balances in Greece, Portugal and Spain. Economic Modelling, 63(1), 143-152.

Lütkepohl, H. (2005). New Introduction to Multiple Time Series Analysis: Springer Science $\&$ Business Media.

Neaime, S. (2015). Twin Deficits and the Sustainability of Public Debt and Exchange Rate Policies in Lebanon. Research in International Business and Finance, 33(1), 127-143.

Papadogonas, T., \& Stournaras, Y. (2006). Twin Deficits and Financial Integration in EU Member-States. Journal of Policy Modeling, 28(5), 595-602.

Vamvoukas, G. A. (1999). The Twin Deficits Phenomenon: Evidence from Greece. Applied Economics, 31(9), 1093-1100.

Xie, Z., \& Chen, S.-W. (2014). Untangling the Causal Relationship between Government Budget and Current Account Deficits in OECD Countries: Evidence from Bootstrap Panel Granger Causality. International Review of Economics \& Finance, 31(1), 95-104. 
ييوست ا: روند نرخ هاى ارز حقيقى

كلمبيا

مكزيك rer
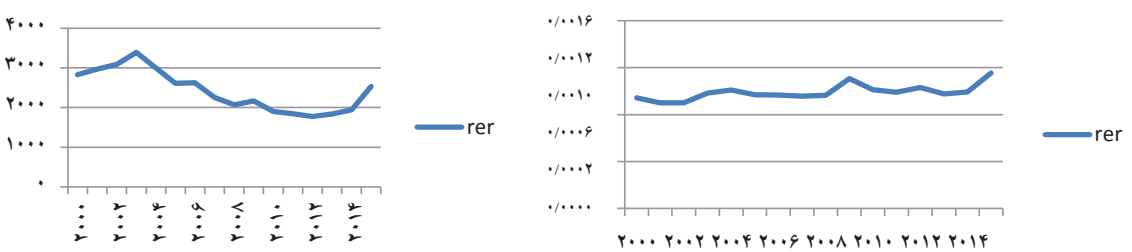

نمودار إ: روند نرخهاى ارز حقيقى كلمبيا

نمودار rإ: روند نرخهاى ارز حقيقى مكزيك

rer

الجزاير
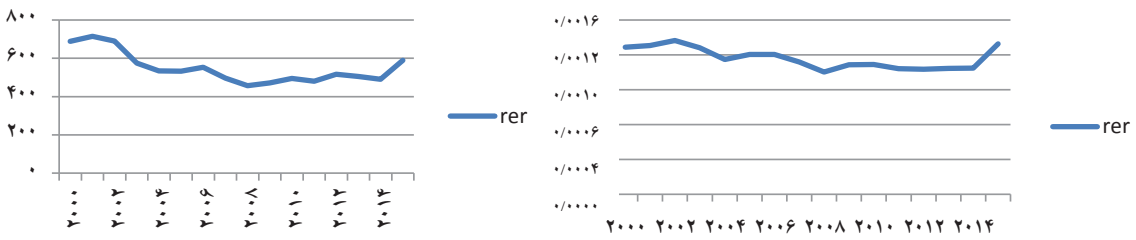

نمودار إِ: روند نرخهاى ارز حقيقى الجزاير نمودار بإ: روند نرخهاى ارز حقيقى كابن

rer اكوادور

ايران رسمى rer
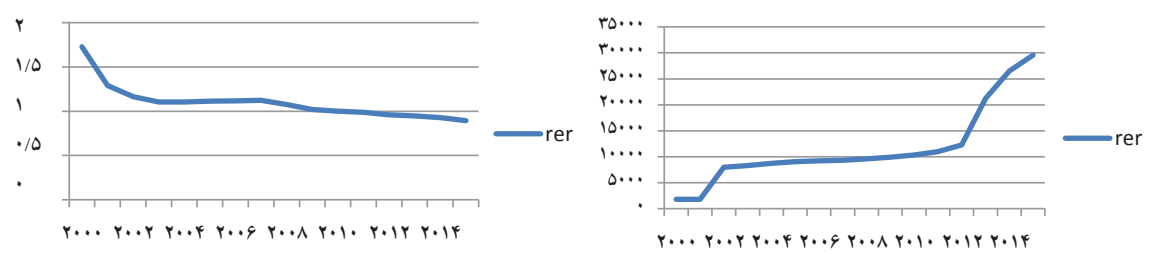

نمودار ها: روند نرخهاى ارز حقيقى اكوادور

نمودار وب: روند نرخهاى ارز حقيقى ايران 
نيجريه rer

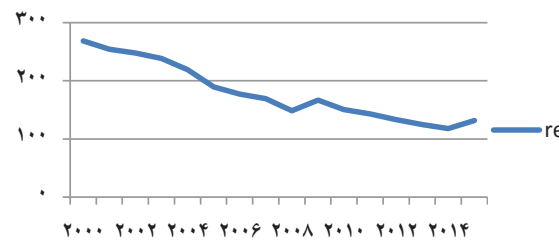

نمودار \إ: روند نرخهاى ارز حقيقى نيجريه

rer آنخولا

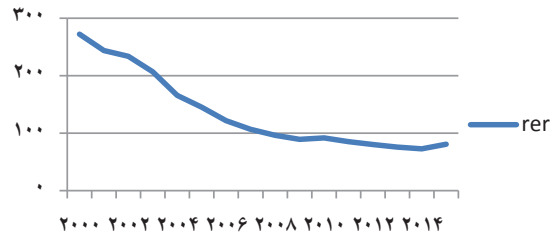

نمودار وب: روند نرخهاى ارز حقيقى آنغولا

اندونزى
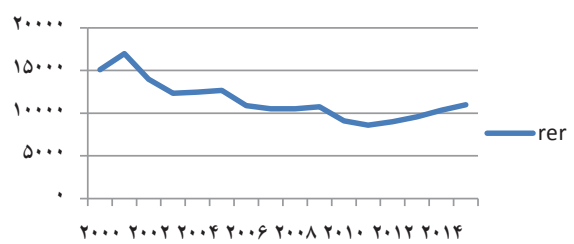

نمودار 1 إ: روندنزخهاى ارز حقيقى اندونزى

بحرين

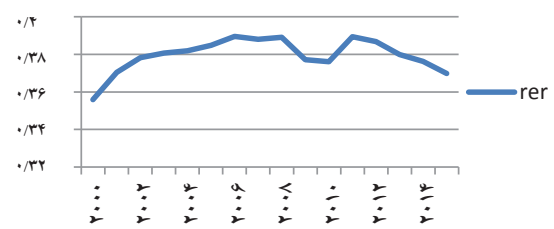

نمودار باي: رونل نخ هاى ارز حقيقى بحرين

عربستانrer

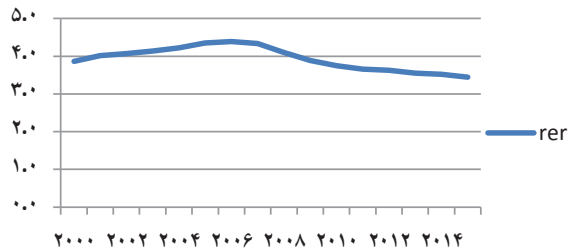

نمودار ^ي: روند نرخهاى ارز حقيقى عربستان

كنكو rer

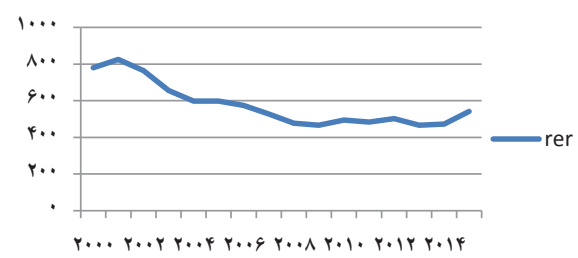

نمودار •اب: روند نرخهاى ارز حقيقى كنغو

مالزى

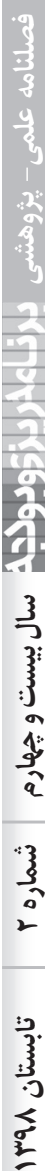

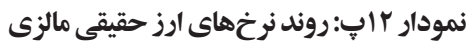

ونزوئلاrer

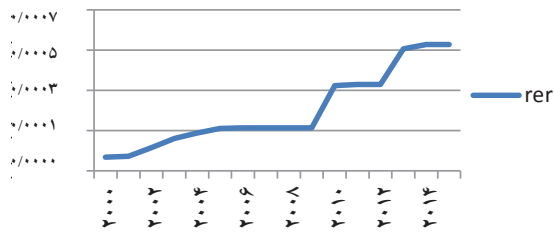

نمودار fا إ: روند نرخهاى ارز حقيقى ونزوئلا 
"ييوست ץ: روند كسرى بودجه، كسرى حساب جارى، و در آمدهاى نفتى

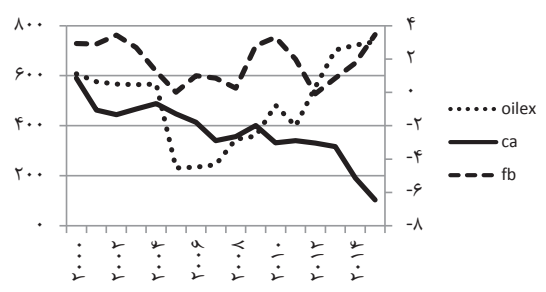

نمودار اب: روند كسرى بودجه، كسرى حساب جارى، و در آمدهاى نفتى كلمبيا

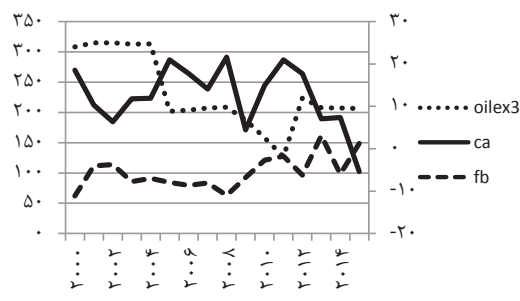

نمودار ساب: روند كسرى بودجه، كسرى حساب جارى، و در آمدهاى نفتى كابن كابن

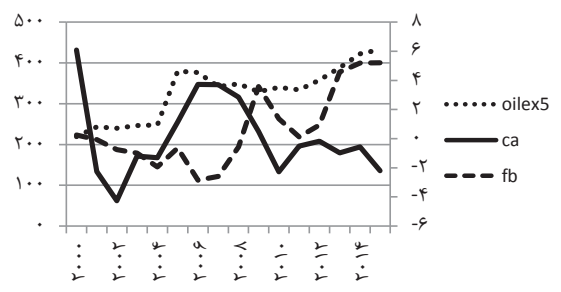

نمودار هٍ: روند كسرى بودجه، كسرى حساب جارى، و در آمدهاى نفتى نمونى اكوادور

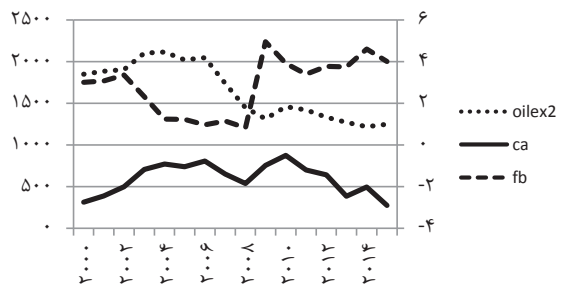

نمودار بإ: روند كسرى بودجه، كسرى حساب جارى، و در آمدهاى نفرى نودجى مكزيك

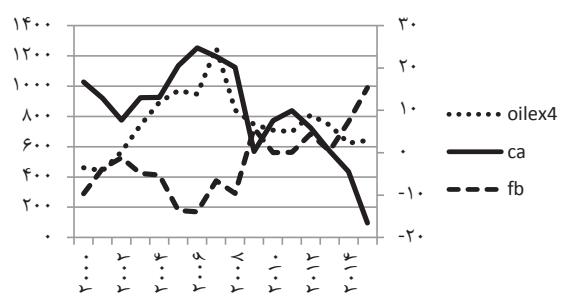

نمودار † پ: روند كسرى بودجه، كسرى حساب جارى، و در آمدهاى نفى بودجى الجزاير

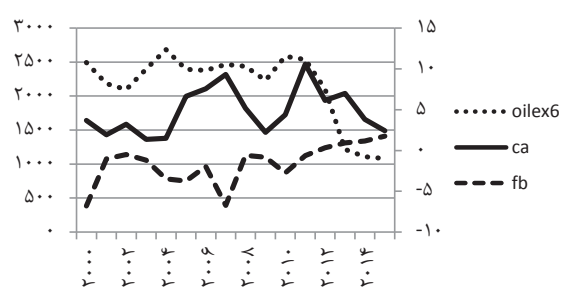

نمودار وي: روند كسرى بودجه، كسرى حساب جارى، و در آمدهاى نفتى اير ان 


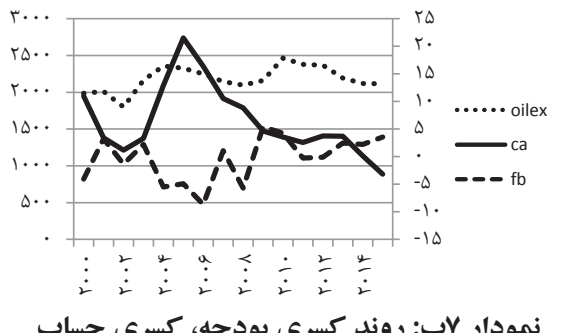

نمودار Yپٍ: روند كسرى بودجه، كسرى حساب جارى، و درآمدهاى نفتى نيجريه

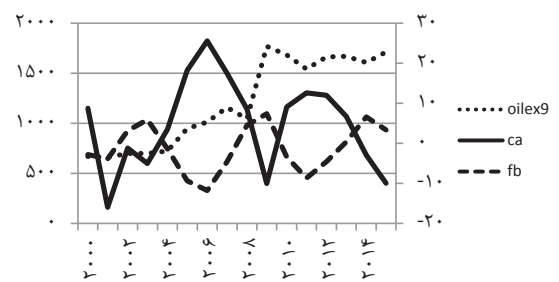

نمودار وِ: روند كسرى بودجه، كسرى حساب جارى، و در آمدهاى نفتى آنتولا

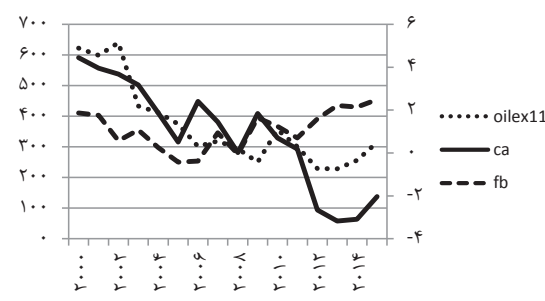

نمودار ال»: روند كسرى بودجه، كسرى حساب جارى، و در آمدهاى نفتى اندونزى

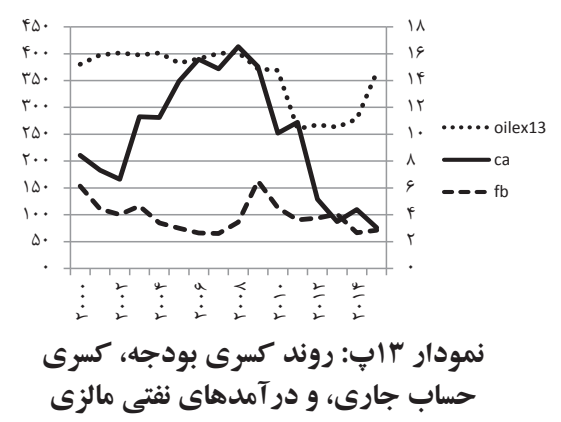

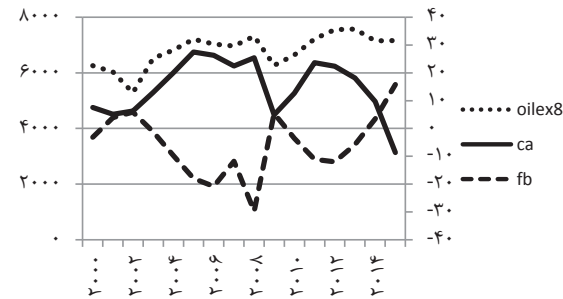

نمودار ^ي: روند كسرى بودجه، كسرى حساب جارى، و در آمدهاى نفتى عربست ودئن

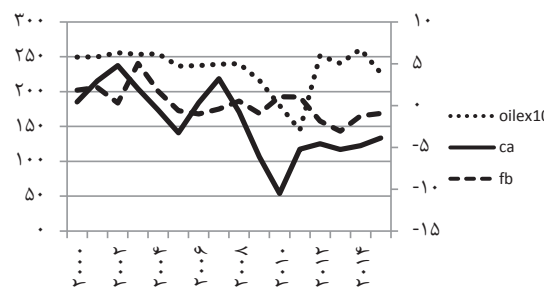

نمودار • إٍ: روند كسرى بودجه، كسرى حساب جارى، و درآمدهاى نفتى كنغو

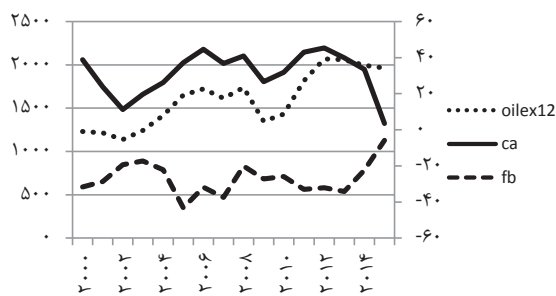

نمودار ץ إڤ: روند كسرى بودجه، كسرى حساب جارى، و در آمدهاى نفتى كويت

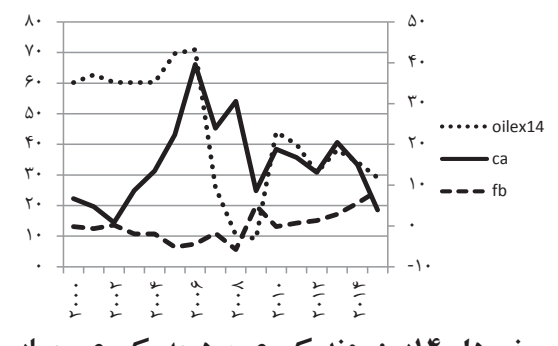

نمودار ^اب: روند كسرى بودجه، كسرى حساب جارى، و در آمدهاى نفتى ترينيداد و توباتو 